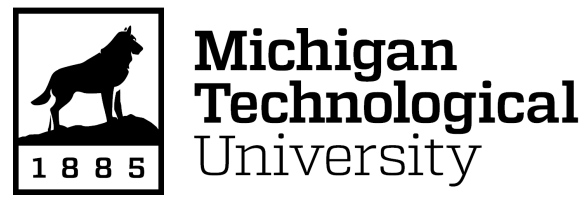

Michigan Technological University Digital Commons @ Michigan Tech

2016

\title{
MODELING SPRING CATCHMENT DISCHARGE: A CASE STUDY OF CANDELA, PANAMA, CENTRAL AMERICA
}

Jordan P. Van Sickle

Michigan Technological University, jpvansic@mtu.edu

Copyright 2016 Jordan P. Van Sickle

\section{Recommended Citation}

Van Sickle, Jordan P., "MODELING SPRING CATCHMENT DISCHARGE: A CASE STUDY OF CANDELA, PANAMA, CENTRAL AMERICA", Open Access Master's Report, Michigan Technological University, 2016.

https://doi.org/10.37099/mtu.dc.etdr/217

Follow this and additional works at: https://digitalcommons.mtu.edu/etdr

Part of the Geology Commons, Hydrology Commons, and the Water Resource Management Commons 


\title{
MODELING SPRING CATCHMENT DISCHARGE: A CASE STUDY OF CANDELA, PANAMA, CENTRAL AMERICA
}

By

Jordan P Van Sickle

\begin{abstract}
A REPORT
Submitted in partial fulfillment of the requirements for the degree of MASTER OF SCIENCE

In Geology
\end{abstract}

MICHIGAN TECHNOLOGICAL UNIVERSITY

2016

(C) 2016 Jordan Van Sickle 
This report has been approved in partial fulfillment of the requirements for the Degree of MASTER OF SCIENCE in Geology.

Department of Geological/Mining Engineering and Sciences

\author{
Report Advisor: John S Gierke \\ Committee Member: $\quad$ Zhen Liu \\ Committee Member: $\quad$ David Watkins
}

Department Chair: John Gierke 


\section{Table of Contents}

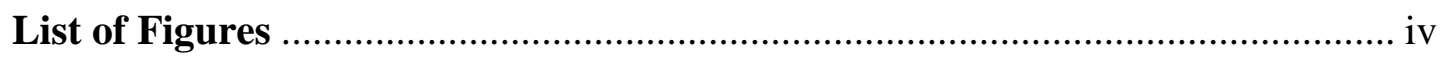

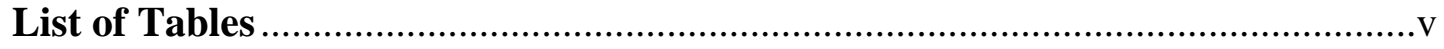

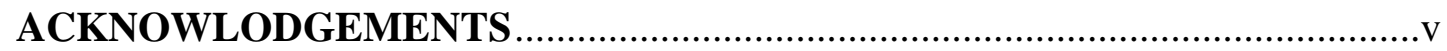

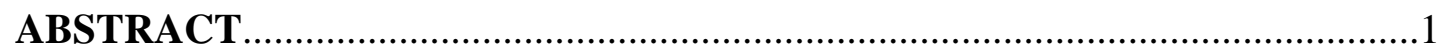

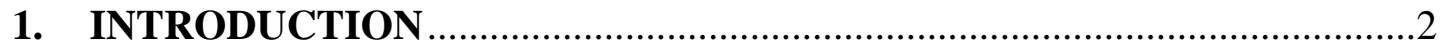

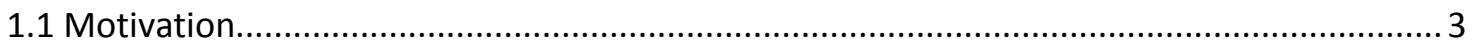

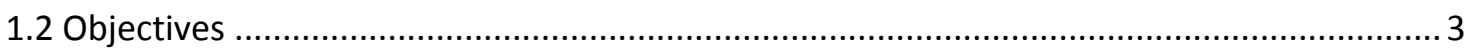

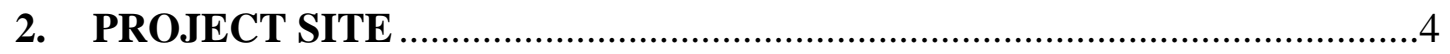

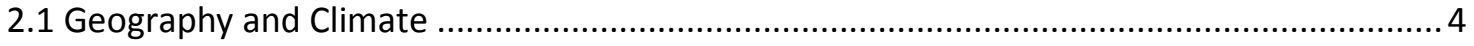

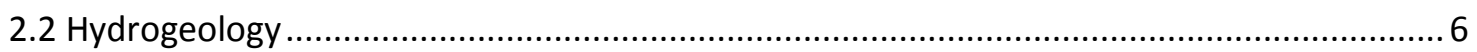

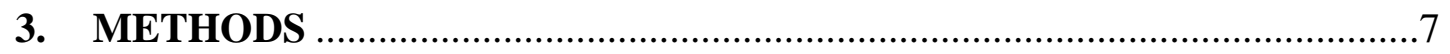

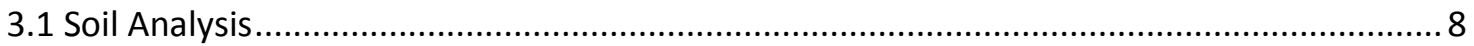

3.1.1 Saturated Hydraulic Conductivity ………………………………….....

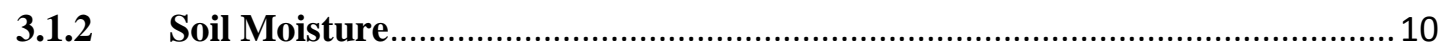

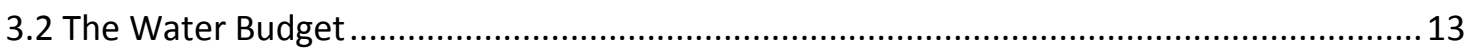

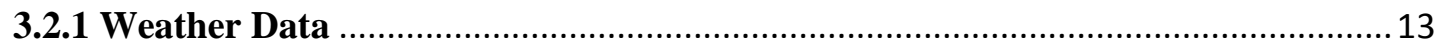

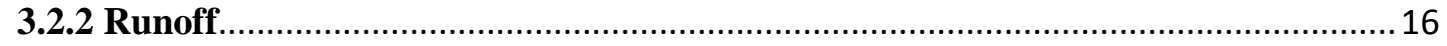

3.2.3 Monthly Water Balance Model............................................................................ 16

3.3 Spring Recession Analysis ...................................................................................... 19

3.3.1 Discharge collection ........................................................................................ 19

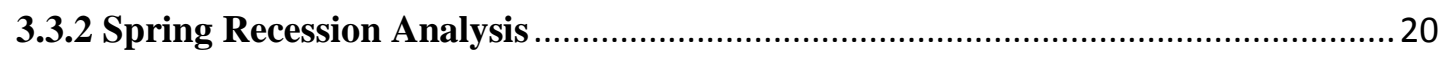

3.4 Groundwater Flow Model...................................................................................2 22

3.4.1 Model Configuration ....................................................................................2

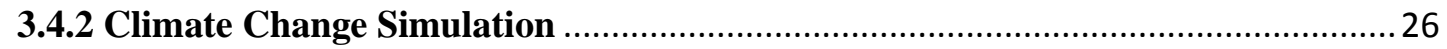

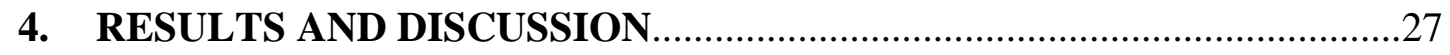

4.1 Soil Tests, Water Balance and Recession Analysis ........................................................2

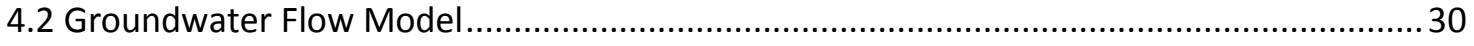

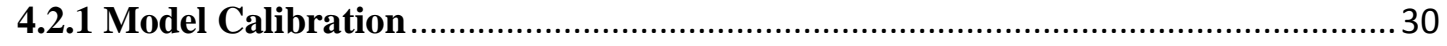

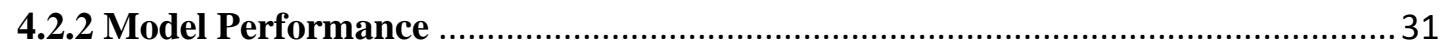

4.2.3 Climate Scenarios....................................................................................................

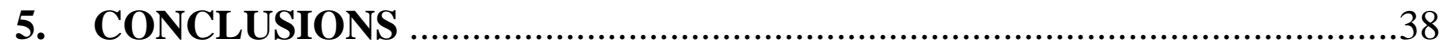


6. FUTURE WORK

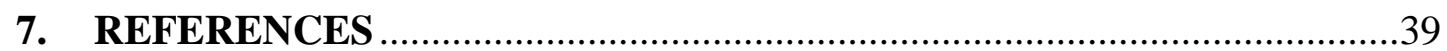

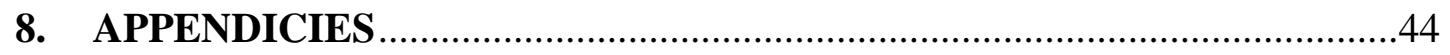

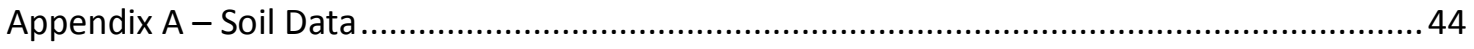

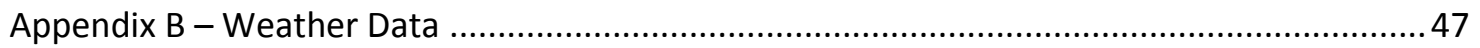

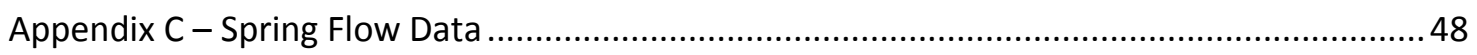

\section{List of Figures}

Figure 1. Comarca Ngabe Bugle boundary highlighted in red cover 8.5\% of Panama. The black diamond represents the project site (Courtesy of Wikimedia Commons and

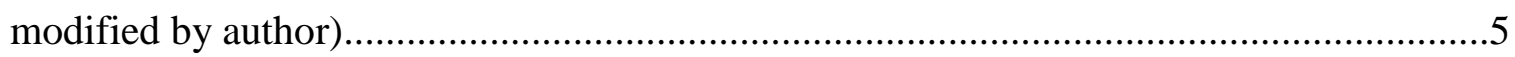

Figure 2. Annual rainfall in western Panama (Courtesy of ETESA, 2014).........................6

Figure 3. Photo of Upper Spring during dry season exposing local stratigraphy: thick brown topsoil covering a reddish andesite where springs exit, overlying an impervious grey basalt. Photo taken by author, February 2014 ......................................................

Figure 4. Constant head permeameter schematic of setup and use....................................

Figure 5. Field capacity soil moisture conditions (The COMET Program) ........................13

Figure 6. Monthly temperature and rainfall surrounding the Candela watershed ............15

Figure 7. Spring hydrograph and rainfall in the Candela watershed ...............................19

Figure 8. 3D grid model configurations displaying the "wedge-shaped" geometry of Model 1 and the "draped" geometry of Model 2 .........................................................24

Figure 9. TMWB model graphically illustrating monthly relationships between soil moisture, precipitation, evapotranspiration and recharge in the Candela watershed.........29

Figure 10. Baseflow recession curve including flow projections from Maillet equation..30

Figure 11. MODFLOW model simulations compared to the Observed Flow.

Figure 12. A) Cross sectional view of Model 2 in MODFLOW exhibiting initial cell

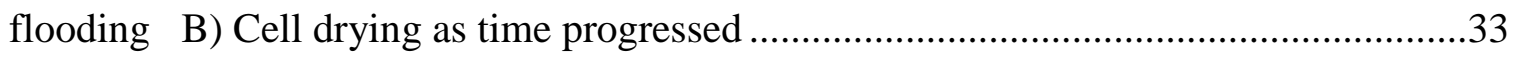

Figure 13. Shaded area represents the range of flows based on ranges of hydrologic parameters in Model 1

Figure 14. Selected climate change simulation results for Model 1 ..................................36

Figure 15. Selected climate change simulation results for Model 2 ..................................37 


\section{List of Tables}

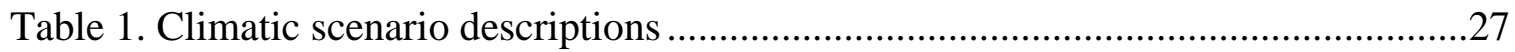

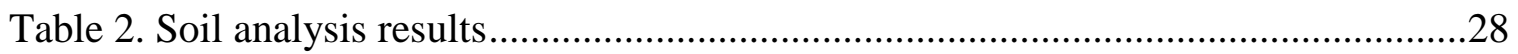

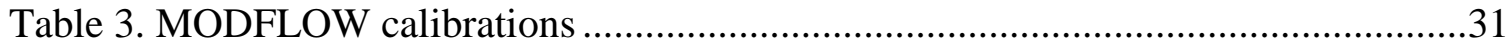

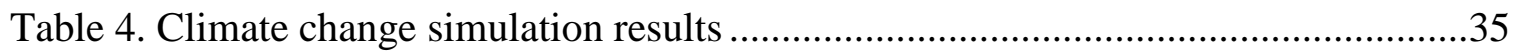

\section{ACKNOWLODGEMENTS}

My friends and family in the community of Candela, Panama deserve my utmost gratitude for all their help and patience dealing with Nido. Küin krebäde jutda. Those in my PCV family are too numerous to name, but deserve credit for my physical and emotional survival of Peace Corps, especially Sally Alsup, Pete and Kelly, Bri Drake and Mike Matthews.

I am grateful to my advisor, Dr. John Gierke, for his assistance and patience throughout my Peace Corps service and time at Tech. Many thanks to my committee members, Dr. Zhen Liu and Dr. David Watkins, for their reviews and support.

I must also thank the other graduate students at MTU that assisted me, especially Chet Hopp, Nate Arnold, Federica Lanza, Luke Bowman and Alex Wohlgemuth, they each helped me often and are much loved. Finally, my parents, Adam and Aaron have supported me from near and far, and this thesis would not have been possible without their steadfast love. 


\begin{abstract}
Where the proper geological and hydrological conditions exist, natural springs have provided a reliable source of clean water to mankind for eons. Changing climates and land development can negatively impact spring source replenishment and threaten their reliability as a source of water. In the face of prospects of diminishing supplies and increasing population demands, community leaders question whether and how to invest in development for enhancing sustainability and protecting water quality, causing water managers to dispute their reliability given decreasing flows. Springs located in the rugged jungle of western Panama serve as the primary water supply for many indigenous communities, such as Candela, which hosts a population of 140. The author of this report lived in that remote community for two years working with the water committee leaders to develop their spring-dominated water supplies. With a lack of data and the physical understanding of the hydrological principles, people often speculate when making water and land use decisions. Objective observational data from monitoring and computational tools for simulating system hydrology would be a valuable platform from which to hold more reasoned discussions on climate impacts and land use to enhance the reliability of water sources. This report characterizes the hydrologic conditions within the watershed that contribute to spring discharge and uses numerical modeling to test hypotheses related to the aquifer mechanics supplying the spring flow. Observations and measurements made within the watershed area included soil conditions, spring flows, and local weather (precipitation and temperature). The data were evaluated using various analytical and numerical methods in an attempt to understand the spring discharge processes relative to the local precipitation. The topography of the catchment area was extrapolated from DigitalGlobe imagery. Soil data analysis provided estimates of infiltration, runoff and recharge rates, which all affect water availability in the shallow groundwater aquifer supplying the springs. A baseflow recession analysis of the combined spring discharge data was performed to quantify the flow behavior of the hydrograph and offer predictions of drought flow behavior. Hydrologic inputs and outputs of the system were accounted for using a basic catchment-scale water budget that produced an annual recharge rate given the variable environmental conditions. These estimates were applied to two groundwater flow models using GMS MODFLOW-2000, each with different aquifer dimensions. The hydraulic conductivity and storativity of the aquifers were calibrated in transient-state simulations to the flow conditions observed during the dry season.

Various climatic scenarios were then applied to the models to evaluate their accuracy of simulated flow to the observed flow and to predict water availability from the springs. Simulations using a thicker aquifer outperformed those using a thinner aquifer by having less flow error and more flexibility under a range of hydrologic conditions. Not only do the parameters defining the aquifer properties control the flow rate, but the volume of storage also plays a seminal role in matching the observed spring behavior within these models. The results suggest that the model aquifer presented here requires substrate that has large enough interstitial storage capacity to accumulate a substantial amount of water, yet exhibits flow paths tortuous enough to slowly release water over time. With plenty of recharge during the wet season, spring discharge is sustained throughout the long dry season by a combination of high infiltration rates of the soil and aquifer material, and sufficient aquifer storage volume and retention.
\end{abstract}




\section{INTRODUCTION}

Natural springs have long been useful to mankind; their origins and processes governing their flows, however, continue to be enigmatic. They are often a clean, reliable water source that can support the establishment of an entire community. Such springs are located in the rugged jungle of western Panama and serve as the primary water supply for the indigenous community of Candela. As population grows and water demand rises, community leaders question investing in their proper development, forcing water managers to quarrel about their reliability. Investing money in construction is a difficult proposition in most sustainable farming communities where excess income is next to nothing. Decisions to build a water storage tank or a catchment box, or lay more pipe are difficult when there is little certainty in the longevity of a water resource. The initiation for this study originates from these types of quarrels observed in various communities around the world that are ripe for water system development and the use of tools required to assess their sustainability.

In order to provide a good foundation for spring resource management, Healy et al. (2007) suggested we must clearly understand the water budget and principal hydrologic processes governing flow. Bryan (1919) classified shallow springs as being sourced by an aquifer whose properties define spring discharge and are largely controlled by stratigraphic and structural features. Aquifer storage properties such as recharge, storativity, and hydraulic conductivity can be assessed by examining spring discharge during the recession period, known as a baseflow recession analysis. Quantifying aquifer contributions to baseflow also requires consideration of the mass water balance of the catchment.

Local weather and soil data are collected in this study to characterize infiltration, runoff, evapotranspiration, and recharge rates that contribute to the available groundwater supply. Groundwater flow models with variable aquifer dimensions are then developed to simulate spring discharge during the recession period in order to quantify properties that control flow from the aquifer. These models are run through numerous scenarios with variable climatic environments in order to test the resiliency of the model and to forecast probable outcomes of spring water availability for domestic use during the dry season. This report documents the utility of using limited field data to create a groundwater flow model that characterizes the hydrology of the springs to be developed in Candela, Panama. 


\subsection{Motivation}

In Candela, community leaders struggle to make appropriate decisions concerning spring water development because they do not recognize the factors contributing to a reliable spring source. Also, many subsistence farming communities and families do not have the means to finance a water system or are simply unwilling to risk investing in an ambiguous project. Organizations who offer financial and technical support for these families often rely on limited local knowledge and inadequate hydrologic data to design these water systems.

As a volunteer working with organizations constructing spring sourced, gravity-fed water systems in Laos, Ecuador and Panama, I found it evident in each project that spring flow was an enigmatic component of both the design and resiliency of the system. Flow patterns change, water evades catchment structures, and springs relocate or even cease to flow altogether, virtually guaranteeing developmental failure. Even when designs are appropriate, spring flows may decrease to a useless state, which wastes both time and money invested in developing the spring and leaves the community both discouraged and without water.

In this study, a watershed containing two natural springs is characterized in a mountainous region of Panama by modeling the aquifer that sources the springs and ultimately controls the timing and volume of their discharge. Factors that contribute to sustaining reliable spring flow will be emphasized through calibrating models to conditions observed in the field for roughly two years and applying various environmental changes to the models to forecast changes in flow. The goal is that this work will assess the practicality of using a groundwater flow modeling program for this hydrologic system and provide a bit of insight into the factors contributing to spring flow.

\subsection{Objectives}

\section{Objective 1: Characterize hydrologic conditions in the Candela watershed to analyze spring discharge during the dry season using a water budget approach, baseflow recession analysis and groundwater flow models.}

Assessing the hydrologic conditions of watersheds is a vital component in quantifying and managing its water supply. Spring water flow can fluctuate tremendously in small watersheds like Candela, largely due to its local climate, soil type and aquifer attributes. Evaluating the watershed conditions can improve the effectiveness of water system development and anticipate short and long term fluctuations that may affect its sustainability. 


\section{Objective 2: Evaluate spring flow response from differing aquifer geometries in a steeply sloped, spring-dominated setting using GMS 9.1 MODFLOW-2000 groundwater modeling software.}

Computer simulation models can offer experimental capabilities allowing hypotheses to be tested that may otherwise be financially or materially unfeasible, especially in cases where field data, such as the subsurface geology, is limited. In the case of groundwater systems, these models can help evaluate risks in water system development from drilling a well to designing storage tanks to investing in the watershed altogether. The intention of this study is to highlight the elements controlling flow and expose the limitations in modeling groundwater flow to springs.

\section{PROJECT SITE}

\subsection{Geography and Climate}

Panama is the southernmost country in Central America, bordered by Costa Rica to the west and Columbia to the east. Located near the equator ( $7-10^{\circ}$ latitude), it is an isthmus bounded by the Caribbean Ocean to the north, the Pacific Ocean to the south, and is capped by the rugged Cordillera Central Mountains (see Figure 1).

Upon the arrival of Europeans in Panama during the $16^{\text {th }}$ century, people of the Ngäbe (pronounced No-bay) indigenous tribe were steadily displaced from the fertile lowlands to the mountainous jungles along the Cordillera Central (Young P.D. and Bort J.R., 2001). In 1997, the Panamanian government established an autonomous region in western Panama for this tribe called the Comarca Ngäbe-Buglé (CNB). The terrain in the CNB is characterized by steep slopes, abundant watercourses, and sporadic non-terraced farmland interspersed in a dense tropical forest. 


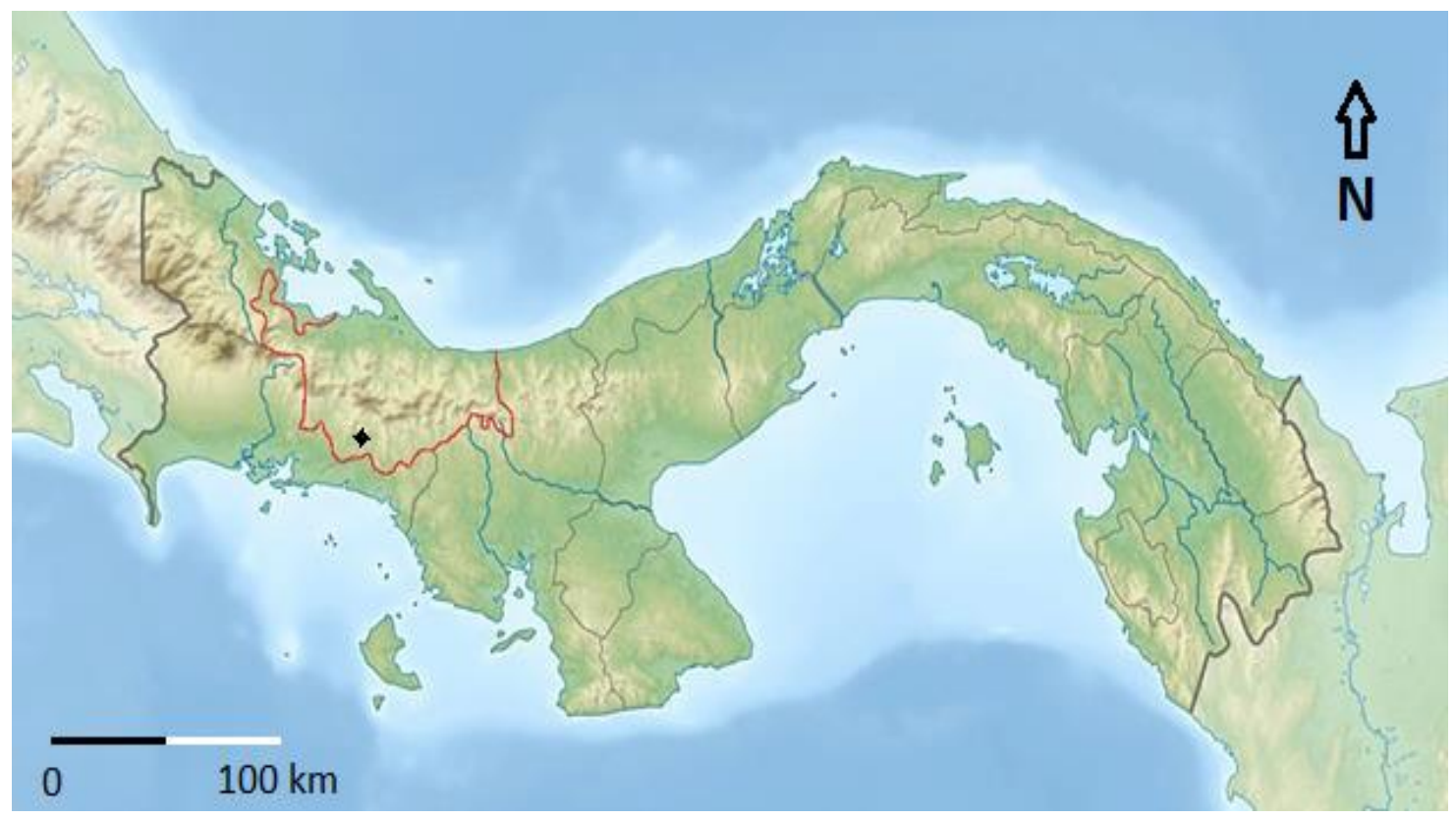

Figure 1. Comarca Ngabe Bugle, boundary highlighted in red, covers $8.5 \%$ of Panama. The black diamond represents the project site (Courtesy of Wikimedia Commons and modified by author)

This study was conducted in a small watershed within the CNB located directly upslope of the small Ngäbe village of Candela (Figure 1), population 140. The Ngäbe people are primarily subsistence farmers who practice slash-and-burn agriculture to grow corn, beans, and rice on plots typically less than 5 acres. Land cover within the watershed is primarily undisturbed jungle, although two small homesteads are at the top of the watershed, roughly 130 meters upslope from the springs. The watershed comprises about 10 acres of heavily forested steep slopes on a northwest aspect, with elevations ranging from 300 mamsl to 380 mamsl. The two springs surface at the lower end of a $20^{\circ}$ slope along an ephemeral stream at elevations of roughly 306 mamsl and 321 mamsl, respectively.

The climate of the project site in western Panama is tropical, warm and wet. Precipitation varies seasonally and annually, as shown below in Figure 2. Temperatures are relatively constant, averaging $24{ }^{\circ} \mathrm{C}$ during the rainy season and $26^{\circ} \mathrm{C}$ during the dry season. The project watershed has a distinct wet season that typically occurs from mid-April to midDecember followed by a distinct dry season lasting from mid-December to mid-April with an average rainfall of $167 \mathrm{~mm} /$ season. Wet season storm events occur frequently (daily), generally have moderate rainfall intensities and typically last several hours to several days. Dry season storm events are infrequent, typically last less than an hour, and have either high or very low rainfall intensities. 


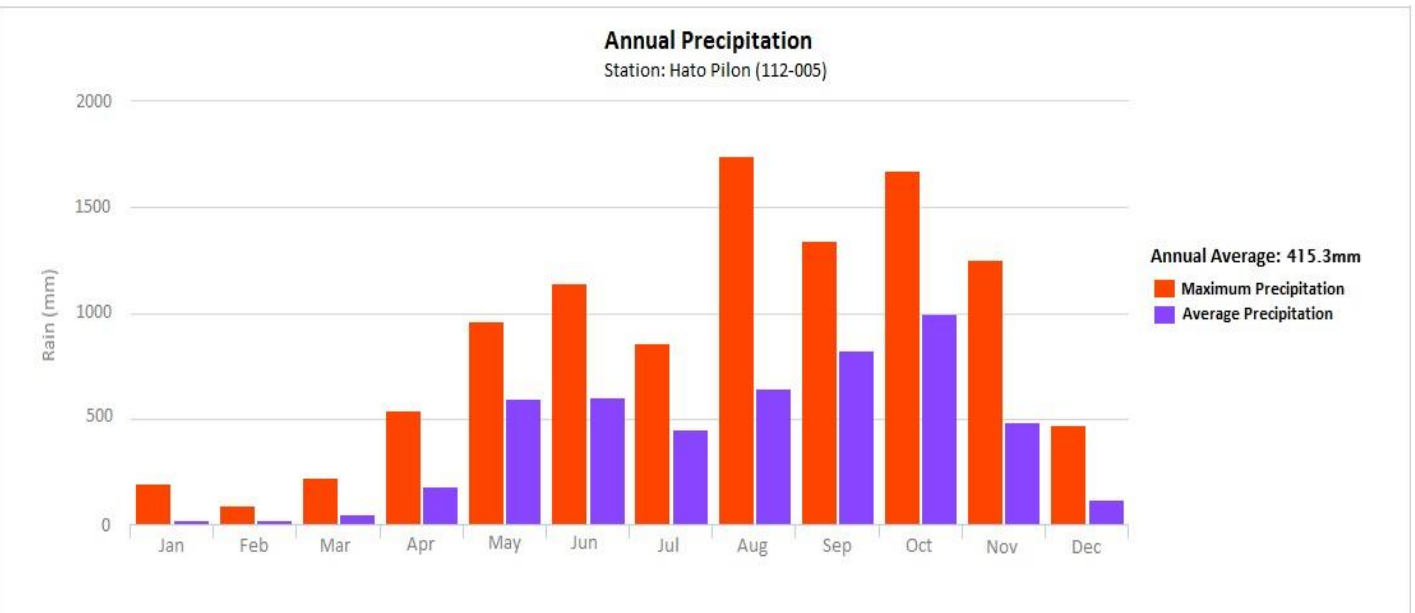

Figure 2. Annual rainfall in western Panama (Courtesy of ETESA, 2014)

\subsection{Hydrogeology}

The geology of the region is a product of complex tectonic activities between the Nazca, Cocos and Caribbean plates (Harmon R.S., 2005) that produced intermediate-mafic material deposited from around 90 Ma to recent volcanic events on Mt. Baru occurring around 400-500 years ago (Sherrod et al., 2007). The watershed is located along the foothills of the uplifted volcanic material where erosion dominates landscape formation. Rock outcrops composed of basalt, andesite and dacite exhibit high humic alteration at and near the surface in the form of iron and manganese redox reactions. The predominantly clay-rich soil derives its constituents from weathering minerals, including: calcite, limonite, gibbsite, ferrihydrite, kaolinite, and allophane.

The outcrop at the springs exposes the soil and volcanic stratigraphy within the watershed (Figure 3). Generally, it consists of $0-1.5$ meters of brown topsoil overlying 1-4 meters of highly fractured, reddish andesitic tuff on top of more competent brecciated basaltic bedrock. Natural springs along the slope discharge at or near the tuff/basalt stratigraphic contact, including the two springs analyzed in this report. Faults and stratigraphic contacts capture diffuse matrix seepage and preferentially convey groundwater flow, which can channelize subsurface flow and expand incipient fracture systems. These conduits increase erosion towards the surface, creating a depression spring that typically coincides with the stratigraphic contacts. The springs issue from incipient fracture systems and conduits along both the subsoil-andesite and andesite-basalt contacts. Both the stratigraphy and relatively quick fluctuations in spring discharge suggest a thin shallow aquifer, probably laminar or tapered in shape, comprised of clay-rich soil upon andesitic tuff overlying more impermeable brecciated basalt. The two aquifer structures represented in a groundwater modeling program are based on these hypothesized laminar and tapered geometries. 


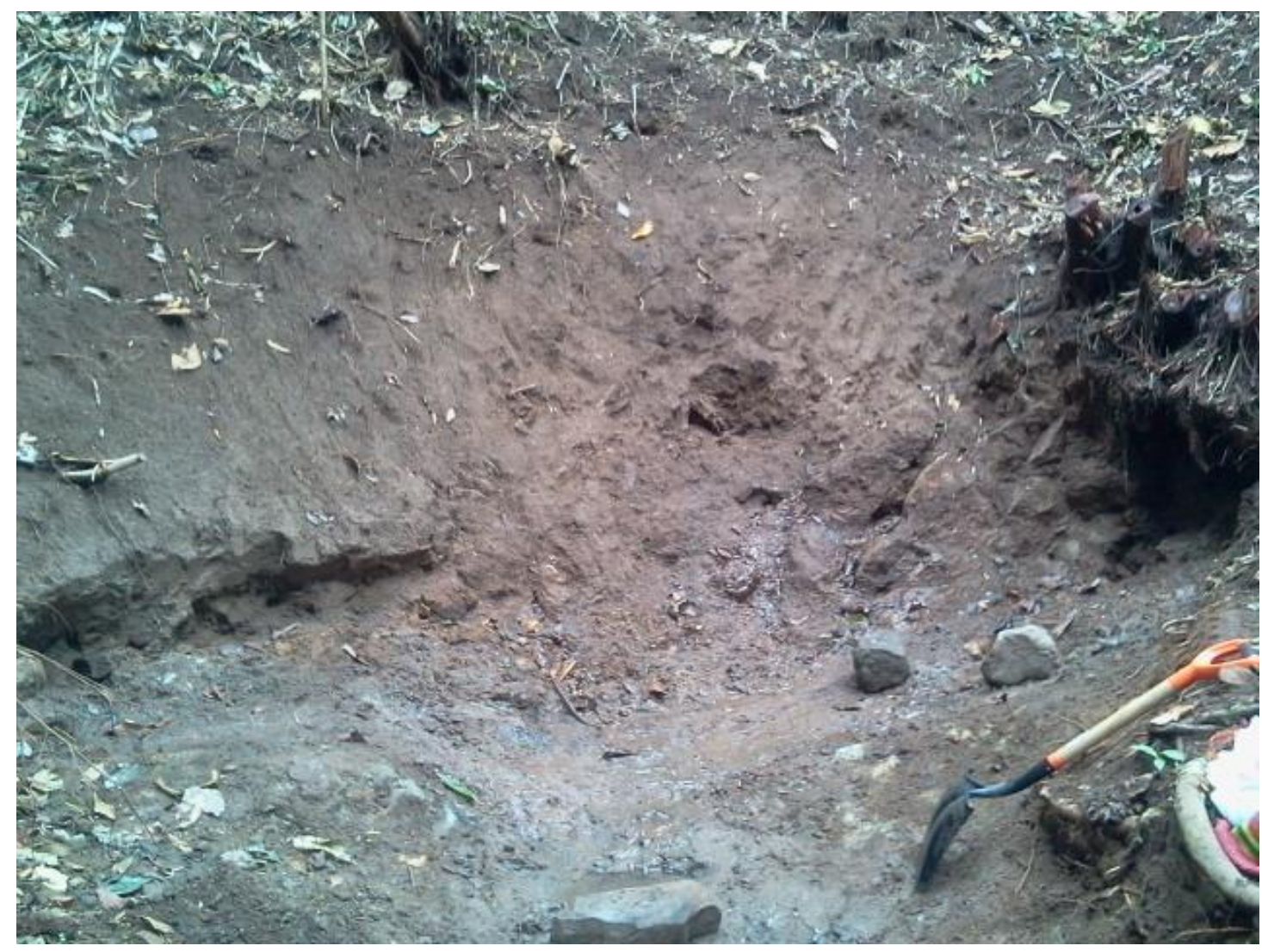

Figure 3. Photo of Upper Spring during dry season exposing local stratigraphy: thick brown topsoil covering a reddish andesite where springs exit, overlying an impervious grey basalt. Photo taken by author, February 2014.

The watershed exists on a relatively isolated slope along a ridge surrounded by steep slopes on all sides. It is bounded by creeks on each side with no perennial springs upslope or downslope of the two springs analyzed in this report. The detached nature of the watershed reduces the probability of groundwater input into the aquifer from adjacent catchments, offering a more closed system of recharge and discharge, simplifying the water budget analysis.

\section{METHODS}

To simulate the available water from the springs in the Candela watershed during the dry season, a catchment characterization was performed and the conditions in the subsurface hydrology were simulated using a groundwater flow model. The topography of the catchment area was identified first by coupling GPS field measurements with DigitalGlobe imagery. Weather and infiltration data were collected in the field and 
applied to the Thornthwaite-Mather monthly water budget to estimate the annual recharge to the aquifer. Discharges from two springs within the watershed were measured throughout the wet and dry seasons, compared in a graphical recession analysis and used to calibrate conditions for two spatially distinct aquifers using the groundwater flow modeling program GMS 9.1 MODFLOW-2000, or MODFLOW. Following calibration of the groundwater models, climatic variations in precipitation and temperature for the watershed were applied to the water budget to approximate recharge values and simulated in MODFLOW to assess model performance under drought-like conditions.

\subsection{Soil Analysis}

Soil analysis within the watershed provides data for the water budget analysis, a field reference of hydraulic conductivity for the shallow aquifer models, as well as insight into aquifer recharge and storage capacity. Soil composition, porosity, strata and conductivity were analyzed to provide a range of values for soil field capacity, root zone depth, specific yield and saturated field hydraulic conductivity. Potential aquifer storage depends on infiltration rate, storage capacity and the specific yield of the porous media.

\subsubsection{Saturated Hydraulic Conductivity}

Constant-head permeameter tests were performed at six locations within the watershed to estimate field saturated hydraulic conductivity $\left(K_{s a t}\right)$ in order to analyze soil infiltration and aquifer recharge. Figure 4 illustrates the permeameter configuration where the change in reservoir volume is measured over time. $K_{s a t}$ is found when the flow rate $\left(Q_{s}\right)$ entering the ground is constant which is sourced from the reservoir that supplies water at a constant pressure at a specified depth within the borehole. The consistent pressure enables a constant flow of water from the reservoir despite decreasing water level. 


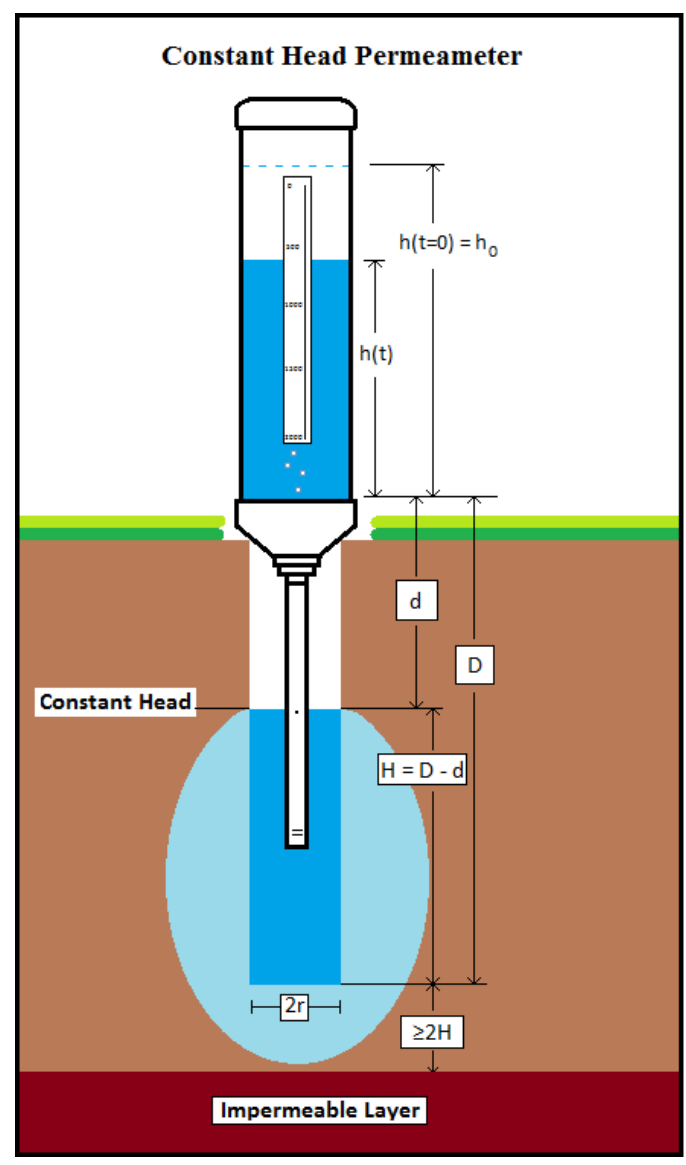

Figure 4. Constant head permeameter schematic of setup and use (sketched by author)

The steady-flow component was analyzed using the Glover solution (Zangar, 1953) to estimate $K_{\text {sat }}$, which considers the water "bulb" geometry in the borehole (Figure 4). The tests were first developed in an attempt to understand soil-water relationships when maintaining a thin layer of water on the surface, i.e. constant head on an unsaturated soil with a deep water table. The solution is:

$$
\begin{gathered}
K_{\text {sat }}=A Q_{s} \\
A=C / 2 \pi H^{2} \\
C=\sinh ^{-1}(H / r)-\left((r / H)^{2}+1\right)^{1 / 2}+r / H \\
K_{\text {sat }}=Q_{s} *\left(\sinh ^{-1}(H / r)-\left(\left((r / H)^{2}+1\right)^{1 / 2}+r / H\right) / 2 \pi H^{2}\right)
\end{gathered}
$$

where $K_{\text {sat }}\left(\mathrm{cm} /\right.$ day) is the hydraulic conductivity of the field saturated soil; $Q_{s}\left(\mathrm{~cm}^{3} /\right.$ day) is the steady-state discharge of water from the reservoir; $r(\mathrm{~cm})$ is the radius of the borehole; and $H(\mathrm{~cm})$ is the height of the water column in the borehole. This solution 
provides more accurate estimates of $K_{\text {sat }}$ when a large $\mathrm{H} / \mathrm{r}$ ratio $(\mathrm{H} / \mathrm{r} \geq 10)$ is established (Zangar, 1953; Elrick and Reynolds, 1992), and the bedrock or impermeable layer and the ground water table are $\geq 2 \mathrm{H}$ distance below the borehole, so the wetting front is not immediately affected by these boundaries. Equation 4.2 does not take into account gravity flow through the base of the borehole (Reynolds et al. 1983), potentially causing an overestimation in $K_{\text {sat }}$.

Eight constant-head permeameter tests were performed in the watershed located at various locations upslope of the springs. Each borehole was made using a 7-cm diameter steel hand auger creating boreholes roughly $7-8 \mathrm{~cm}$ in diameter. The depths of each hole are limited either by the length of the auger $(56 \mathrm{~cm})$ or by bedrock/hard rock within the borehole $(<56 \mathrm{~cm})$. The permeameter was filled with clean water to the top of the scale and placed in the borehole, and time measurements were recorded at each scale increment. Steady-state flow was observed once the air bubbles were uniform in frequency and flow rate from the reservoir into the soil stabilized. Several refills of the reservoir were necessary to achieve stabilization during the end of the dry season tests. After testing, each borehole was excavated to hard rock depth to gauge test accuracy.

Steady-state flow is reached more quickly in the saturated zone than the unsaturated zone, and the higher the hydraulic conductivity, the quicker steady-state flow can be reached in the unsaturated zone (Stephens and Neuman, 1982b). The application of the Glover solution to the constant-head arrangement becomes less accurate as the shallow aquifer deviates from being isotropic, homogeneous and of uniform thickness, as well as if the bedrock is less than $2 \mathrm{H}$ deeper than the bottom of the hole. It unrealistically assumes that flow into and through the soil occurs under saturated conditions, as it is based on the Laplace equation. The solution could provide inaccurate estimates for $\mathrm{K}_{\text {sat }}$ as it ignores unsaturated flow conditions based on borehole geometry due to a non-uniqueness to the $C$ and $H / r$ ratio (Stephens and Neuman, 1982a) and in dry soils (Elrick and Reynolds, 1992).

\subsubsection{Soil Moisture}

Soil density, porosity, specific yield and field capacity were estimated from soil samples and soil profile assessments to provide an improved approximation of aquifer recharge. Several centimeters of dense leaf litter generally cover the watershed on rugged, steep ground in dense vegetation. In general, trails and distinct drainage basins display high storm runoff and erosion during the wet season, with minimal runoff occurring in the densely covered forest. Prismatic, massive, and granular soil structures were observed within the watershed, suggesting a range of mostly finer soil material and high seasonal variability in moisture. 
Soil profile characteristics listed in Appendix A were determined from 4 excavated boreholes. The assessments included: soil color, soil texture, organic material, and root zone depth. Grain size analyses were completed using the ribboning method modified from Milford (2010) on 19 samples taken at various depth intervals, and using a field hydrometer adapted from Thein (1979) on 2 samples. These particle distribution tests measure clast size and sorting that offer insights into effective porosity and field capacity of the soil. The field hydrometer test was performed by collecting a soil sample in a cylindrical jar, adding water and laundry detergent and mixing the contents to separate the particles. The height measurements of each particle size were taken at distinct time intervals during the settling process: coarse particles of sand and gravel are measured after 45 seconds, silt particles after 3 hours, and clay particles after 48 hours.

Additional soil samples were collected in order to estimate the field capacity of the soil by measuring soil moisture content, bulk density, and porosity. Two samples were collected in situ at depths of $1-11 \mathrm{~cm}$ and $30-40 \mathrm{~cm}$, transported to the lab in jars and weighed using an A\&D EK410i scale (standard deviation of $0.01 \mathrm{~g}$ ) before and after drying for 21 hours at $\sim 250^{\circ} \mathrm{F}$ in a conventional oven. Soil bulk density, or dry bulk density, incorporates in situ soil properties, such as compaction and porosity, and is expressed as:

$$
\rho_{b}=M_{s} / V_{t}
$$

where:

$\rho_{b}=$ Dry bulk density of the soil $\left(\mathrm{g} / \mathrm{cm}^{3}\right)$

$M_{s}=$ Mass of dry sample $(\mathrm{g})$

$V_{t}=$ Volume of soil sample $\left(\mathrm{cm}^{3}\right)$

Soil porosity was calculated by dividing the bulk density of a material by the particle density $\left(\rho_{b}\right)$. An average value for particle density is $2.65 \mathrm{~g} / \mathrm{cm}^{3}$, therefore soil porosity percentage can be expressed as:

$$
\Phi_{s}=\left(1-\rho_{b} / \rho_{p}\right) * 100
$$

where:

$\Phi_{s}=$ Porosity of the soil (\%)

$\rho_{b}=$ Bulk density of the soil $\left(\mathrm{g} / \mathrm{cm}^{3}\right)$

$\rho_{p}=$ Particle density $\left(\mathrm{g} / \mathrm{cm}^{3}\right)$ 
The soil porosity describes the potential void space and the maximum water storage capacity of the soil medium. Some water is retained in the unsaturated zone through capillary action which reduces recharge to the aquifer. The effective porosity accounts for this retention of fluid and quantifies the water available for fluid flow. The specific yield $\left(S_{y}\right)$, or drainage porosity, approximates the effective porosity and is a ratio of the volume of water that drains by gravity to the total volume of the soil. $S_{y}$ was estimated by comparing grain size results from the field to acceptable average specific yield values for unconsolidated soil materials presented by Johnson (1967) (Appendix A). The $S_{y}$ of the unconsolidated material can be used to define the soil field capacity which is utilized in the Thornthwaite-Mather water balance method. The soil field capacity, $\theta_{f c}$, can be expressed as:

$$
\theta_{f c}=\Phi_{s}-S_{y}
$$

where:

$\theta f_{c}=$ field capacity of the soil

$\Phi_{s}=$ porosity of the soil

$S_{y}=$ specific yield of the soil

Illustrated in Figure 5, the field capacity is the upper limit of the water holding capacity of the soil once rapid drainage by gravitational forces become negligible, excluding evapotranspiration processes. It is a function of particle surface area and is contingent on structural and textural properties of the soil, where values can be as low as $6 \%$ for sand and as high as $35 \%$ for clay. 


\section{Soil Moisture Conditions for Various Soil Textures}

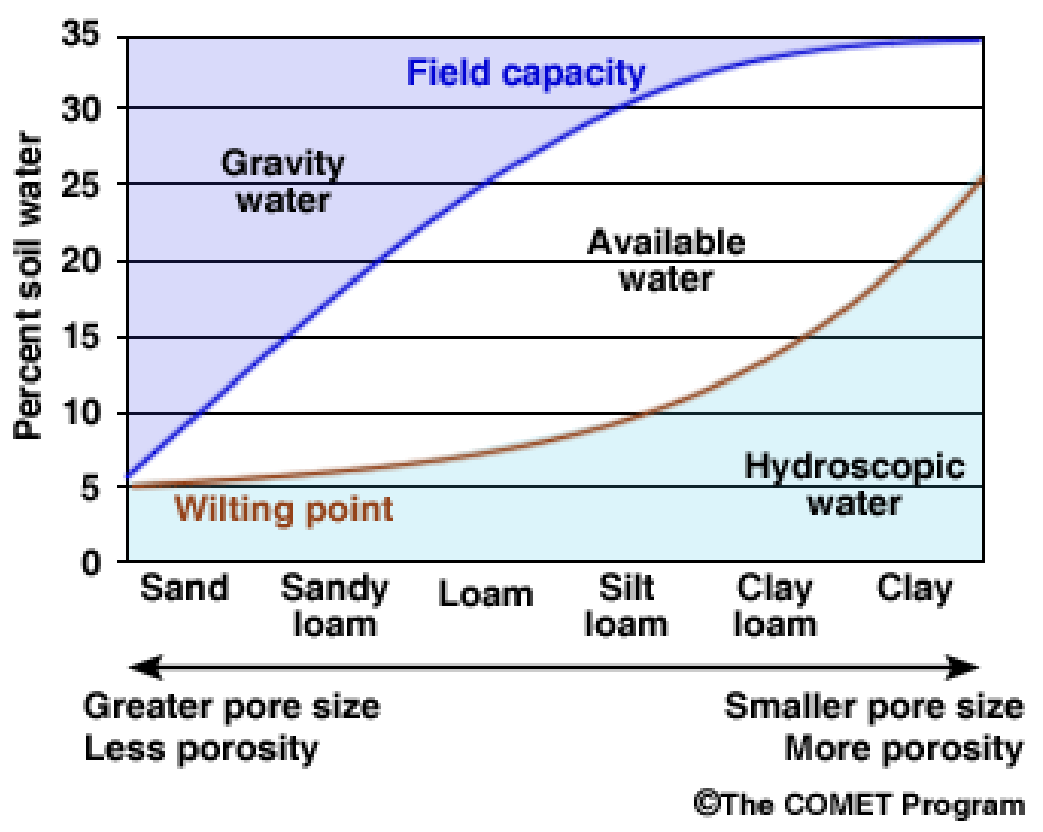

Figure 5. Field capacity soil moisture conditions (generated by The COMET Program)

\subsection{The Water Budget}

A water budget states that the rate of change in water stored in an area, such as a spring catchment area, is the difference between the amounts of water that flow into and out of the area. Equation 4.6 defines the change in storage as water inputs of precipitation, subtracted by water outputs of evapotranspiration, surface runoff and recharge:

$$
P-E T-R-Q=\Delta S
$$

This principle was applied to the Candela watershed using a variation of the Thornthwaite-Mather monthly water balance method to estimate groundwater recharge (simplified from Dingman, 2002).

\subsubsection{Weather Data}

Regional and local climate records from five sources were collected to analyze precipitation and temperature contributions to the hydrologic system. Average monthly rainfall was gathered from an onsite temporary weather station and from four permanent government-managed weather stations proximally located near the watershed. 
The permanent weather stations are located between 3 and 11 kilometers from the watershed and contain records dated as far back as January 1971 (Appendix B). These data offer historical monthly rainfall averages for the foothills region where the watershed lies. A high spatial distribution of rainfall exists among the weather stations in the region due to the rugged topography and orographic lifting. To better capture the variability of rainfall within the watershed, the monthly rainfall values at each station were normalized and spatially weighted based on aspect, proximity to, and elevation difference from the watershed. The stations located nearest to the watershed at the closest elevations with a similar aspect to the study watershed were given the most weight in averaging monthly rainfall values. The weighted averages for each month from the 4 permanent weather stations were then averaged with the monthly average rainfall data from the onsite temporary weather station. 


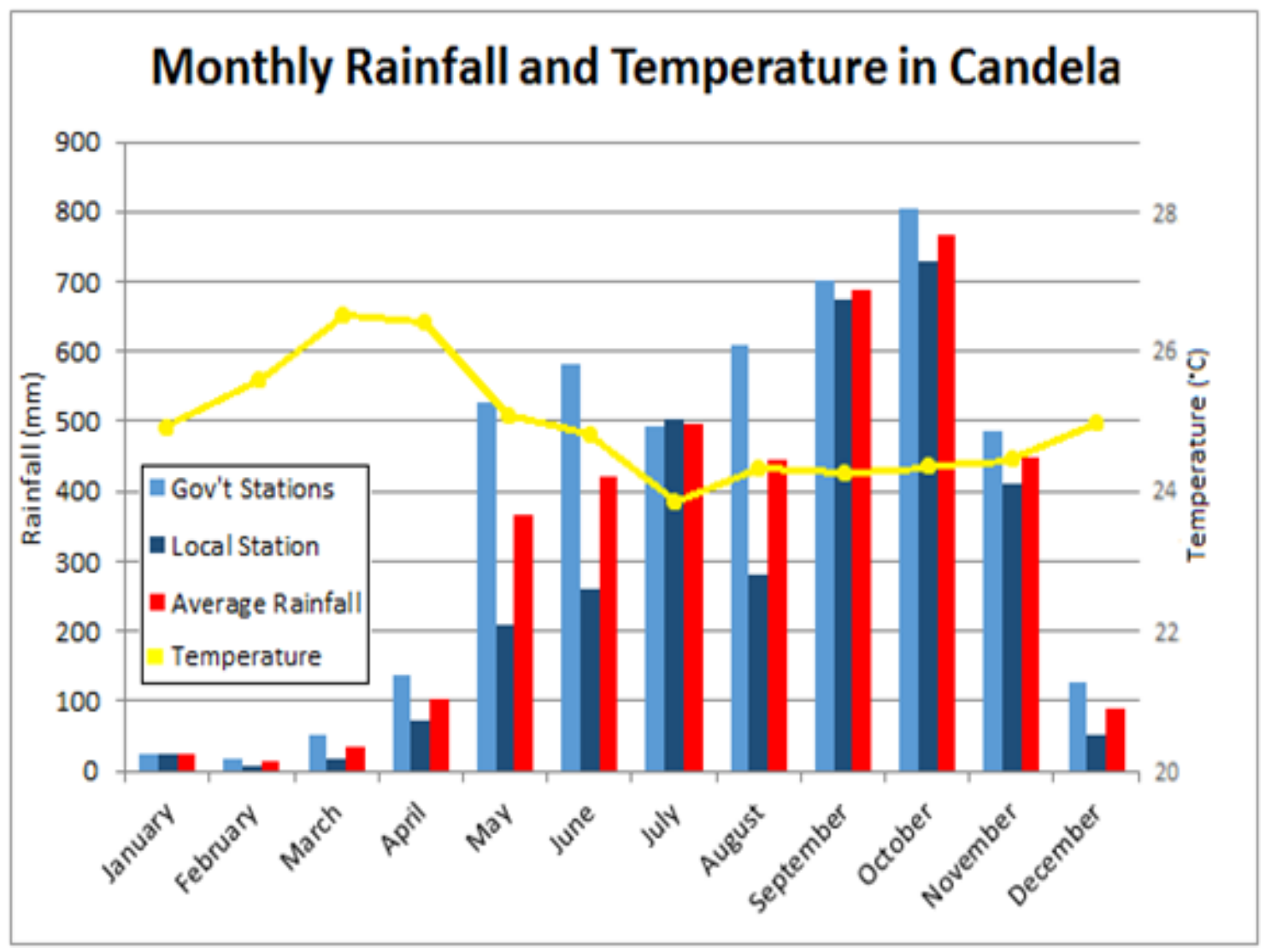

Figure 6. Monthly temperature and rainfall surrounding the Candela watershed

A temporary weather station was erected roughly $0.7 \mathrm{~km}$ from the watershed at an elevation of 290 mamsl to provide proximal daily rainfall and temperature data. The Ambient Weather WS-1090 Wireless Home Weather Station takes continuous measurements of rainfall, temperature, wind speed and direction, barometric pressure and humidity and records at 30 minute intervals. The rain gauge was calibrated using a $10 \mathrm{~mL}$ graduated cylinder, while the orientation of the anemometer was calibrated using a Suunto compass with a declination set to $2.2^{\circ} \mathrm{W}$. From April 19, 2013 until June 7, 2014, 414 consecutive days of rainfall and temperature data were collected, to be used in calculating representative monthly rainfall and temperature values. Figure 6 shows monthly temperature and rainfall values that were averaged with the permanent and temporary station values to obtain the most representative climate information for the water budget. It was assumed that the long-term rainfall values from the governmentoperated stations watershed overestimate conditions for the watershed due to being located at higher elevations and with differing aspects than the study watershed. Conversely, the short-term rainfall data from the onsite station slightly underestimate watershed conditions due to station location lower than the study watershed, as well as its reduced catch due to wind effects. 


\subsubsection{Runoff}

Runoff was observed during rain events in a small ephemeral stream located within the watershed. Spring flows emerge and flow into the ephemeral draw forming a perennial stream. The amount of runoff was estimated using the hourly soil infiltration rate and rainfall intensity. Soil infiltration rates provide an indicator of the potential volume of rainfall being recharged at the surface over time, and the remaining volume is considered runoff. The local weather station provided hourly rainfall measurements over a 365-day period, while 8 permeameter tests yielded an average estimate of the infiltration rate representative of the watershed. The estimated volume of annual runoff was then subtracted from the annual recharge deduced from the water budget.

\subsubsection{Monthly Water Balance Model}

A simple watershed-scale water balance was used to account for the hydrologic processes governing groundwater recharge which supply the springs. This study employed the Thornthwaite-Mather monthly water balance model (TMWB) adapted by Dingman (2002), which uses a temperature-based method by Hamon (1961) to determine potential evapotranspiration and net precipitation. The soil moisture content is found on the assumption that when the saturated soil exceeds the field capacity the excess water percolates downward by gravity beyond the root zone and immediately supplies the aquifer (Thornthwaite, 1948; Mather, 1978). Unsaturated zone processes are omitted in this procedure, which by some are considered to be insignificant, in part, because typical unsaturated zone thicknesses in humid regions are so thin (Romano et al., 1999). The supporting equations for the Thornthwaite-Mather water balance adapted from Shonsey (2009) are:

$$
R_{m}=P_{m}-\Delta S O I L_{m}-E T_{m}
$$

$$
\begin{aligned}
& \text { If } P_{m} \geq P E T_{m} \text { then } E T_{m}=P E T_{m} \text {, but if } P_{m}<P E T_{m} \text { then } E T_{m}=P_{m}-\triangle S O I L_{m} \\
& \qquad S O I L_{m}=S O I L_{m}-S O I L_{m-1} \\
& \text { SOIL }_{m}=\text { SOIL }_{m-1}\left[\exp \left(-\frac{P E T_{m}-P_{m}}{\text { SOIL }_{\max }}\right)\right]
\end{aligned}
$$




$$
\text { SOIL } \max =\theta_{f c} * Z_{r z}
$$

where:

$$
\begin{aligned}
& R_{m}=\text { Monthly recharge (mm) } \\
& P_{m}=\text { Monthly precipitation }(\mathrm{mm}) \\
& P E T_{m}=\text { Monthly potential evapotranspiration }(\mathrm{mm}) \\
& E T_{m}=\text { Monthly actual evapotranspiration }(\mathrm{mm}) \\
& \triangle S O I L_{m}=\text { Monthly change in soil moisture }(\mathrm{mm}) \\
& S O I L_{m}=\text { Present month's estimated soil moisture }(\mathrm{mm}) \\
& S O I L_{m-1}=\text { Previous month's estimated soil moisture* }(\mathrm{mm}) \\
& S O I L_{m a x}=\text { Maximum achievable soil moisture (mm) } \\
& \theta_{f c}=\text { Field capacity of the soil } \\
& Z_{r z}=\text { Vertical extent of the root zone (mm) } \\
& \quad * \text { To start calculations } S O I L_{m-1} \text { is equal to } S O I L_{m a x} \text { representing the end of } \\
& \text { the wet season. }
\end{aligned}
$$

The actual evapotranspiration $(E T)$ is the actual amount of water removed from the surface which equals the potential evapotranspiration (PET) given sufficient precipitation $(P)$. The PET component is a measure of the atmosphere's ability to remove surface water by evaporation and transpiration. There are several methods to calculate PET, but the Hamon method requires fewer variables than alternate methods (Lu et al, 2005) and for this reason was used in this study:

$$
P E T=924 \cdot D \cdot \frac{e_{a\left(T_{a}\right)}^{*}}{T_{a}+273.2}
$$

where:

$$
\begin{aligned}
& P E T=\text { Potential evapotranspiration }(\mathrm{mm} / \text { month }) \\
& D=\text { Day length }(\mathrm{hr}) \\
& e_{a}^{*}=\text { Saturation vapor pressure at the mean daily temperature }(\mathrm{kPa}) \\
& T_{a}=\text { mean daily temperature }\left({ }^{\circ} \mathrm{C}\right)
\end{aligned}
$$

Saturation vapor pressure at the mean daily temperature is estimated as (Dingman 2002): 


$$
e_{a}^{*}\left(T_{a}\right)=0.611 \cdot \exp \left(\frac{17.3 T_{a}}{T_{a}+237.3}\right)
$$

Evapotranspiration is a function of the day length (D) which changes with latitude. It can be calculated with the following equations (Dingman, 2002):

$$
\begin{gathered}
D=2\left(\frac{\cos ^{-1}[-\tan (\delta) \tan (\Lambda)]}{\omega}\right) \\
\delta=0.006918-0.399912 \cos (\Gamma)+0.070257 \sin (\Gamma)-0.006758 \cos (2 \Gamma)+ \\
(4.15) 0.000907 \sin (2 \Gamma)-0.002697 \cos (3 \Gamma)+0.00148 \sin (3 \Gamma) \\
\Gamma=\frac{2 \pi(J-1)}{365}
\end{gathered}
$$

where:

$\Gamma=$ day angle (radians)

$J=$ day number (Julian days)

$\delta=$ sun declination (radians)

$\Lambda=$ latitude (radians)

$\omega=$ Earth's angular velocity $(0.2618$ radians $/ \mathrm{hr})$

There were several limitations and assumptions involved in this water balance method that were taken into consideration during this study. Groundwater flow into the system does not contribute to recharge due to the relatively isolated topography of the watershed, which would otherwise increase recharge estimates. Rainfall interception by vegetation is not accounted for in the TMWB model, an omission that would increase net precipitation values and ultimately recharge estimates. The TMWB model assumes that all the rainfall within any given month evaporates at the single monthly potential evapotranspiration $\left(P E T_{m}\right)$ rate. It uses monthly average values instead of daily or hourly values thereby excluding rainfall intensity from the soil moisture calculations. However, rainfall 
intensity was used to calculate potential runoff. The model also simplifies the soil moisture variance and drying curve using a single value for soil water availability. Both the Thornthwaite and Hamon methods tend to slightly underestimate $P E T_{m}$ up to $15 \%$ (Bakundukize et al., 2011), which, in turn, can overestimate recharge. It is assumed the estimated aquifer recharge may be overestimated and is considered to be an upper limit estimate.

\subsection{Spring Recession Analysis}

\subsubsection{Discharge collection}

Discharge from a spring can be seen as a final result of various processes that govern the conversion of precipitation and other water contributions into a single output at the surface. The springs were selected based on three primary factors: 1) they are the only reasonable perennial water sources available to the community for a gravity-fed water system, 2) they are located in the uppermost portion of the watershed, and 3) their isolated topographic locations offer a more closed system to analyze. Discrete flow measurements were taken for 18 months beginning in December 2012, coinciding with the end of the wet season, until June 2014 at the beginning of the wet season. Sixty-seven measurements were taken intermittently from June 2013 through June 2014, averaging 5 measurements per month (Figure 7).

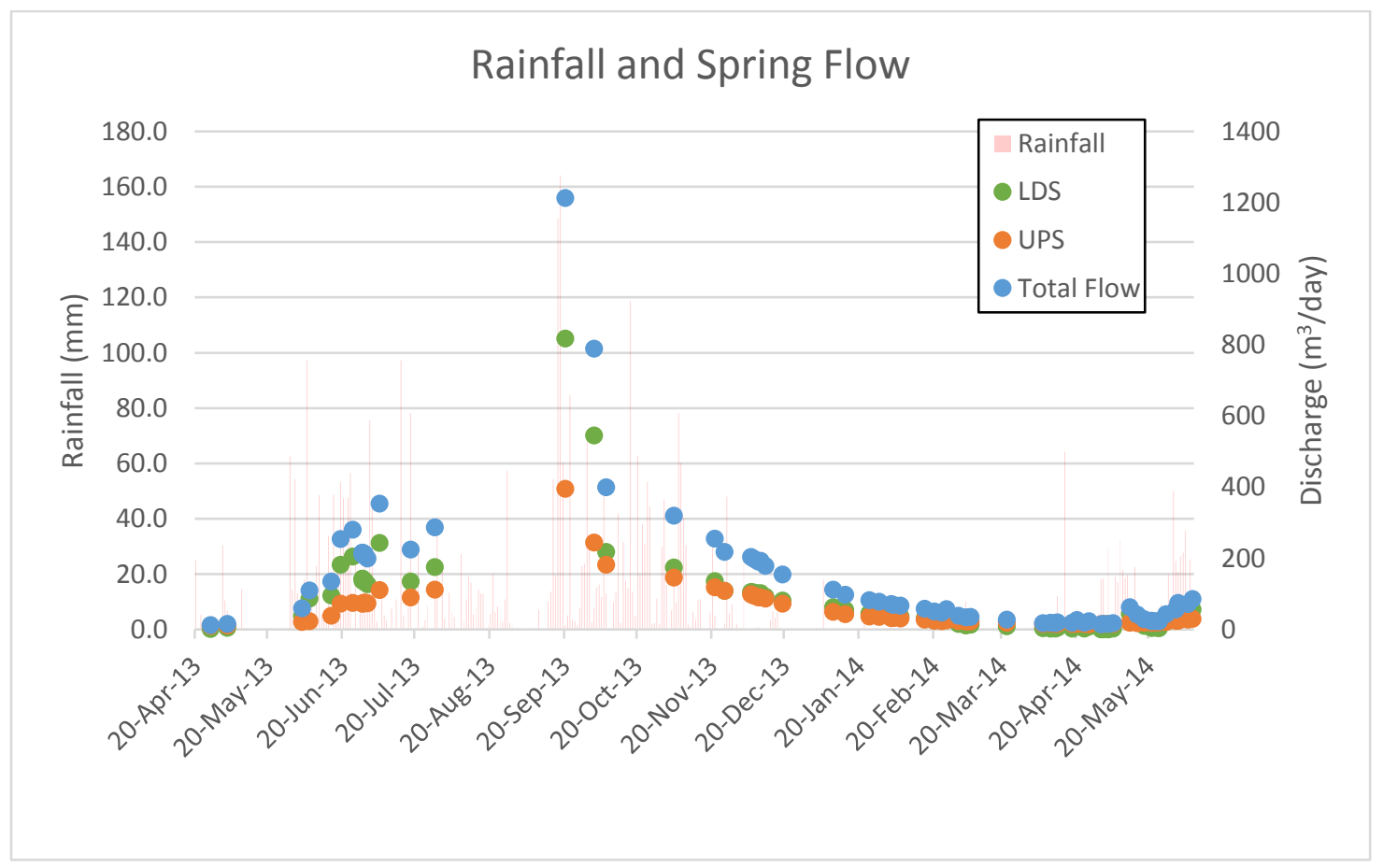

Figure 7. Spring hydrograph of Upper Spring (UPS), Lower Spring (LDS) and combined flow, and daily rainfall in the Candela watershed 
The lower of the two springs (referred to as Lower Spring), was developed in 1999 as the primary water source for the community of Candela. The spring discharge had been partially contained using a concrete box during development, and, although in disrepair upon the author's arrival in 2012, was adequate to channel flows for pipeline conveyance. The other spring (referred to as Upper Spring) that was analyzed is located 49 meters upslope and 14 vertical meters above Lower Spring. There are two distinct discharge locations at Upper Spring situated 4 meters apart along the same contour. Their discharge quantities are different but show similar flow patterns and are therefore combined. The larger spring was left undisturbed during the study until late February 2014 when it was developed using low-head catchment technologies, while the smaller spring was left undisturbed for the duration of the study. Water from both springs was captured by building a semi-permanent dam from local materials and conveyed into a central PVC pipe for measurement.

The spring discharge measurements were collected following the time-volume method using a five-gallon bucket and a stopwatch. To measure flows, the PVC pipe was disconnected from the lower water system 4 meters below the spring orifice and collection point, allowed to stabilize at the spring for approximately one to three minutes, and the bucket was filled and timed. The spring flows were measured three to seven times per measurement and the average flows were recorded.

Discharge measurements from all three springs for each day were combined into one discharge for this analysis in the groundwater flow model. Individual and total spring flow measurements are compiled in Appendix C. Since the measurements were taken roughly once a week, weekly averages of flow were used to represent the end-of-season spring discharges. In both 2013 and 2014, the dry season concluded at the end of the $3^{\text {rd }}$ week in April, and therefore the averages of weeks 3 and 4 were used to calculate the representative flow. The wet season roughly concluded during the last week of November, and therefore the averages of week 4 in November and week 1 in December were used.

\subsubsection{Spring Recession Analysis}

A hydrograph of a spring plots discharge as a function of time and generally includes three parts: the rising limb, the peak, and the recession period. In many cases, it can resemble hydrographs of streams, especially if the aquifer is unconfined and responds rapidly to water inputs (Kresic, 1997). Aquifer recharge from precipitation, groundwater flow and gravitational drainage of soil moisture all may contribute to baseflow discharge (Hall, 1968). Under this definition of baseflow, recession analysis proves most accurate in watersheds that exhibit extended periods of little to no precipitation in order to 
constrain aquifer storage conditions. In this study, analyzing the recession period of the spring hydrograph offered insight into the aquifer behavior by exposing trends in baseflow. The recession period is characterized as the duration between peak flows, generally occurring in October in Panama, and the lowest flows before seasonal precipitation commences, often occurring in May. During a recession, the rate of discharge typically attenuates (without any influence from inputs like precipitation or changes in groundwater flow) due to the reduction in the horizontal and vertical aquifer extent.

A more conventional graphical analysis of spring flow during the recession period was performed as a comparison in addition to modeling the spring flows with a groundwater flow model. Baseflow recession is commonly analyzed either mathematically or graphically using the recession curve (Hall, 1968). Work by Hewlett and Hibbert (1963) in steep mountain watersheds located in humid areas suggests that soil moisture recharges the aquifer in a nonlinear fashion, generating a nonlinear flow response in the hydrograph. Under these considerations, and given the study site environment, a nonlinear approach to baseflow recession was taken using the Maillet (1905) formula, which is an approximate analytical solution for the diffusion equation in porous media. Work done by Dewandel et al. (2003) suggests this equation better estimates the recession curve for hydrographs with steep falling limbs, which can otherwise be overestimated. Used as an exponential function:

$$
Q_{t}=Q_{o} e^{-\alpha\left(t-t_{0}\right)}
$$

where:

$t=$ time during the recession period

$t_{0}=$ time at the beginning of the recession period

$Q_{t}=$ spring discharge at time $t$

$Q_{o}=$ initial spring discharge at the beginning of the recession

$\alpha=$ coefficient of discharge

The coefficient of discharge is dependent on the aquifer transmissivity and specific yield. When plotted on a semilog diagram, the Maillet equation is a straight line and $\alpha$ is its slope: 


$$
\begin{gathered}
\log Q_{t}=\log Q_{o}-0.4343 *(\alpha \Delta t) \\
\alpha=\frac{\left(\log Q_{0}-\log Q_{t}\right)}{0.4343 *\left(t-t_{0}\right)}
\end{gathered}
$$

The conversion factor of 0.4343 in Equation 4.19 was used as it is a more convenient way to express discharge in $\mathrm{m}^{3} / \mathrm{sec}$ and the time in days (Kresic, 2010). When forecasting spring discharge during an extended drought, the optimal coefficient of discharge to apply from the Maillet equation is the gentlest slope at the end of the known recession period. It is assumed the slope of this coefficient best represents drought-like flow conditions.

\subsection{Groundwater Flow Model}

Two experimental groundwater flow models were developed to simulate observed spring discharges and their response to projected climate variation. MODFLOW-2000 was used to simulate groundwater flow using the pre-/post- processing interfaces of Groundwater Modeling Systems (GMS) Version 9.1. Developed by McDonald and Harbaugh (1988), Harbaugh and MacDonald (1996) and Harbaugh et al. (2000), MODFLOW is a modular three-dimensional, finite-difference flow model that uses a numeric solution for the equation governing groundwater flow through porous media. This simulation program is applied by many international, federal, state and private organizations and is considered the most complete simulation program to explore groundwater flow scenarios (EMS-I, 2009). Each groundwater flow model was assigned a distinct aquifer geometry based on plausible geologic conditions. Recharge rate derived from the TMWB method was applied equally to both models during the wet season, while aquifer storativity and hydraulic conductivity were calibrated to match the observed spring flows during the dry season. Once calibrated independently, the performance of Models 1 and 2 was compared and contrasted in the various climatic scenarios.

\subsubsection{Model Configuration}

Catchment area delineation is critical in establishing aquifer size, groundwater flow patterns and water contribution to the hydrologic system. The Candela catchment area, roughly $0.04 \mathrm{~km}^{2}$, was defined topographically in the conceptual model from GPS measurements and field observations. A Garmin GPSMAP 60CSx (WAAS-enabled accuracy of $<5 \mathrm{~m}$, barometric accuracy $<3.048 \mathrm{~m}$ ) was used to gather waypoints and track data along topographic highs and at spring locations. Surface elevations were 
interpolated from a publicly available DigitalGlobe ${ }^{\text {TM }}$ SRTM 30-m DEM taken 3/5/2006. A 2D Scatter Data set of the surface topography was constructed and interpolated to the $3 \mathrm{D}$ grid using the quadratic natural neighbor method. Natural neighbor is an interpolation method offered in GMS that is similar to nearest neighbor interpolation method but applies interpolating weights based on the intersectional area of the Voronoi cell with all adjacent cells. The perimeter of the catchment area consists of 'No-Flow Boundary' arcs where zero flux occurs.

Two models were developed with plausible and unique aquifer geometries in order to better constrain unknown aquifer dimensions (Figure 8) and were evaluated using MODFLOW. The depositional structure of the water-bearing andesitic tuff layer was modeled as a wedge-shaped apron in Model 1, and as a more laminar or draped apron in Model 2 set at a uniform thickness of $10 \mathrm{~m}$.

The conceptual model of the catchment area was simply delineated as one homogeneous, isotropic, unconfined layer due to limited subsurface data. A $5.26 \mathrm{~m}$ x $5.26 \mathrm{~m} \mathrm{x} b \mathrm{~m}$ cell size ( $b$ represents aquifer thickness) is defined in the 3D grid model of MODFLOW. Top layer elevations of the model were assigned to the surface topography which ranged from 304 - 385 mamsl. Bottom layer elevations are what differentiate Model 1 and Model 2 configurations by their unique aquifer thicknesses. Bottom layer elevations in Model 1 are level at 303 mamsl producing a range of layer thicknesses from 1 to $81 \mathrm{~m}$, whereas the bottom layer elevations in Model 2 were designed to be offset from the top layer elevations by a uniform layer thickness of $10 \mathrm{~m}$. The starting heads were set to the surface elevation of each cell to simulate saturated conditions upon model initiation at the end of the wet season. 


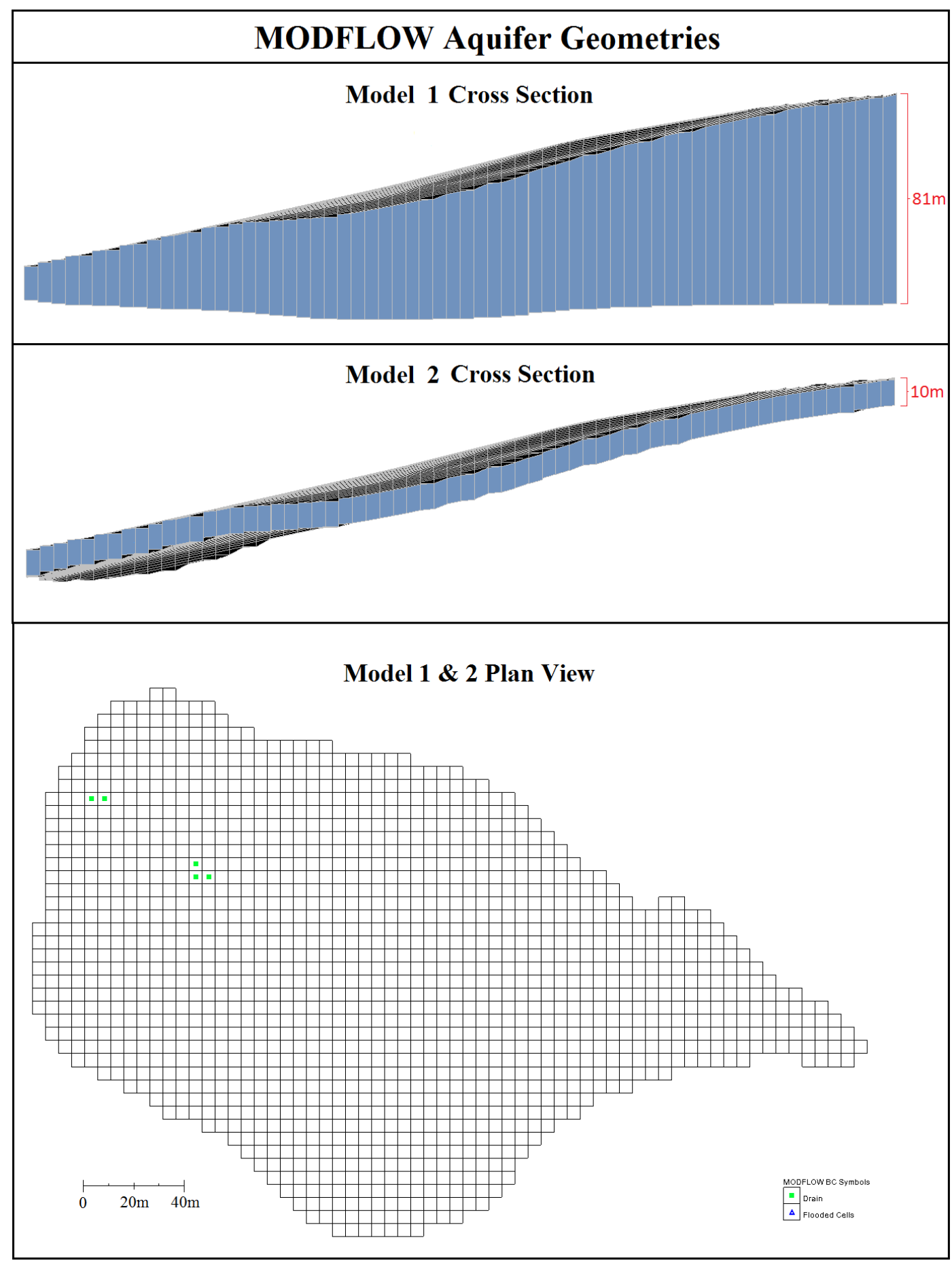

Figure 8. 3D grid model configurations displaying the cross sections along the long axis and the plan view of the "wedge-shaped" geometry of Model 1 and the "draped" geometry of Model 2

The configuration with variable aquifer thickness in Model 1 represents a flat or gently sloping impermeable bedrock layer whose contact with the surface generates the spring. Several large rock outcrops (located $150 \mathrm{~m}$ west of the watershed in an analogous 
environment to the Candela spring locations) exhibit a series of andesitic flows with irregular geometries that are deposited on a gently-dipping, basalt-rich sequence suggesting a flatter impermeable layer in relation to the slope. Field observations of the majority of springs occurring on the slope along this mountain range suggest a contact with this denser basalt-rich unit where flows discharge at the surface along this contact. The configuration with uniform aquifer thickness in Model 2 represents a sloped unconfined aquifer containing a shallow $(10 \mathrm{~m})$ impermeable layer whose depositional structure largely coincides with the surface topography. Some rock outcrops along drainages, trail cuts, and at spring discharge locations suggest a steeply dipping, extrusive flow unit that may produce this type of aquifer structure.

The Drain Package (DRN) in MODFLOW was used to define spring locations and to represent the hydrologic connection from the unconfined aquifer to the springs. Water outflow in the model is allowed only at the drains which are described by the drain elevation and drain conductance:

$$
Q=C * d h
$$

A drain boundary condition acts as an aquifer outlet only when the groundwater table in the cell is above the drain elevation. Below it, water does not discharge, similar to the natural process in a gravity-fed spring, such as in contact or depression type springs. Hydraulic conductivity is the ability of water to move through the aquifer, while the drain conductance acts like a valve at the outflow of the aquifer. The drain conductance parameter describes the resistance to flow out of the drain during permitted drain flow conditions and considers the substrate that the water exits at the spring locations. It is a product of hydraulic conductivity and cross-sectional area of flow divided by the length of the flow path and is often estimated. Drain conductances of 1 and $2 \frac{m^{2}}{d} / m$ were assigned to Lower and Upper Spring, respectively. These estimates are considered reasonable given a small discharge area and clay-rich impermeable material.

The drain elevations of Lower Spring and Upper Spring were found using an average of GPS waypoints and track measurements. A water-pipe level survey of the springs was completed and used to verify spring elevations relative to each other. The drain bottom elevation assigned to Upper Spring was 321.1 mamsl, while $78 \mathrm{~m}$ to the northwest the drain bottom elevation for Lower Spring was set at 306.9 mamsl.

Given temporal field observations, transient-state simulations were performed in MODFLOW and calibrated to the dry season spring flow observations. Since the degree of soil and aquifer saturation was unknown, a steady-state condition was used to simulate the wet season conditions. Each season was defined as a unique stress period. The wet season was assigned one time step to accommodate steady-state simulations, and the dry 
season stress period contained 30 progressive time steps to increase numerical accuracy and better refine temporal analysis. Both models include the Recharge Package (RCH) in MODFLOW, which was applied at a steady rate during the wet season stress period.

Hydraulic conductivity and storativity of an aquifer help describe the nature of flow in the system. While all other necessary system components were estimated through various techniques, storativity and hydraulic conductivity were calibrated in order to assign aquifer characteristics that best represent discharge at the springs during the recession period. In an unconfined aquifer, specific storage is assumed negligible and storativity is simply the specific yield. This yield must be equal to or less than the effective porosity of the aquifer, which is estimated to be 0.3 in the model configuration.

$$
V_{a q}=A_{a q} * b * S_{y}
$$

Equation 4.21 describes the potential maximum available water by the volume in the aquifer $V_{a q}$, which is the product of the area of the aquifer $A_{a q}$, the saturated thickness $b$, and the specific yield $S_{y}$. The volume of stored water helps control the quantity and duration of the discharges at the springs.

A limitation of this configuration is that the springs offer the only water outlet for the model, eliminating the possibility of groundwater to flow out of the system. It was assumed the bedrock, defined as the bottom elevation boundary of each model, is impervious and does not receive any recharge, and that all water inputs are converted to storage and spring discharge. The impermeable layer contributing to spring effluence is assumed to convey $100 \%$ of the water in the aquifer. Groundwater flow into the model is assumed to be negligible given the distinct topographic isolation of the watershed from the surrounding terrain. Model accuracy is partly diminished by applying uniform values for recharge, storativity and hydraulic conductivity across the entire watershed. By setting the starting heads to the surface elevation, these models assume the aquifer is completely saturated at the end of the wet season.

\subsubsection{Climate Change Simulation}

According to a suite of global climate models (GCMs) and regional climate models (RCMs) used by the Intergovernmental Panel on Climate Change (IPCC) and published by the World Bank in April 2011 (World Bank, 2011), Panama ranks 14 ${ }^{\text {th }}$ among countries most vulnerable to climate change, especially in the agricultural and water resources sectors. Models show that the dry season duration is projected to increase, temperatures will increase up to $1^{\circ} \mathrm{C}$ to $3^{\circ} \mathrm{C}$ by 2050 , and projected annual rainfall is projected to change by $-12 \%$ to $+5 \%$ of normal by 2050 . 
In Candela, fluctuations in spring discharge are primarily caused by climatic variables like drought and severe storms. The models produced in MODFLOW were used to simulate the spring flow response to probable climatic scenarios by applying changes in precipitation, temperature and dry season length. These meteorological changes were calculated and analyzed using the TMWB method to generate an appropriate recharge rate which was applied to the models in MODFLOW.

\section{Table 1. Climatic scenario descriptions}

\begin{tabular}{|c|c|c|c|}
\hline \multicolumn{4}{|r|}{ MODFLOW SIMULATIONS } \\
\hline & Climatic Scenarios & $\begin{array}{l}\text { Recharge } \\
\text { Rate }(\mathrm{m} / \mathrm{d})\end{array}$ & Scenario Descriptions \\
\hline 1 & Baseline & 0.0053 & Calibrated Model, Simulated Normal Conditions \\
\hline 2 & Dry $=1$ Month & 0.0053 & Shortened Dry Season by 1 Month \\
\hline 3 & Dry +1 Month & 0.0053 & Extended Drought for 1 Month Longer \\
\hline 4 & Dry +2 Months & 0.0053 & Extended Drought for 2 Months Longer \\
\hline 5 & Dry +1 Month, $P_{m}+10 \%$ & 0.0061 & Extended Drought for 1 Month Longer, $10 \%$ Monthly Increase in Precipitation \\
\hline 6 & Dry +1 Month, $\mathrm{P}_{m}-10 \%$ & 0.0045 & Extended Drought for 1 Month Longer, $10 \%$ Monthly Decrease in Precipitation \\
\hline 7 & $P_{m}+10 \%$ & 0.0061 & $10 \%$ Monthly Increase in Precipitation \\
\hline 8 & $P_{m}+20 \%$ & 0.0069 & $20 \%$ Monthly Increase in Precipitation \\
\hline 9 & $P_{m}=10 \%$ & 0.0045 & $10 \%$ Monthly Decrease in Precipitation \\
\hline 10 & $P_{m-20 \%}$ & 0.0037 & $20 \%$ Monthly Decrease in Precipitation \\
\hline 11 & $T_{m}+1^{\circ} \mathrm{C}$ & 0.0051 & 1 'C Monthly increase \\
\hline 12 & $T_{m}+2^{\circ} \mathrm{C}$ & 0.0050 & $2^{\circ} \mathrm{C}$ Monthly increase \\
\hline 13 & $T_{m}+2^{\circ} \mathrm{C}$, Dry +1 Month & 0.0050 & $2{ }^{\circ} \mathrm{C}$ Monthly Increase, Extended Drought for 1 Month Longer \\
\hline 14 & $T_{m}+3^{*} \mathrm{C}, \mathrm{P}_{m}-12 \%$ & 0.0039 & $3^{\circ} \mathrm{C}$ Monthly Increase, $12 \%$ Monthly Decrease in Precipitation \\
\hline 15 & $T_{m}+3^{\circ} \mathrm{C}, \mathrm{P}_{m}-12 \%$, Dry +1 & 0.0039 & $3^{\circ} \mathrm{C}$ Monthly increase, $12 \%$ Monthly Increase in Precipitation, Extended Drought for 1 Month Longer \\
\hline
\end{tabular}

Columns 1 and 2 in Table 1 illustrate the different climatic scenarios and corresponding estimated recharge rates. These scenarios vary in the duration of the dry season, changes in monthly precipitation, $P_{m}$, and changes in monthly temperature, $T_{m}$. Monthly changes in $T_{m}$ and $P_{m}$ values were put in the TMWB model to generate the recharge rate adjustment. Climate Scenario 1, or the 'baseline' scenario, represents the calibrated model that is simulated using the recharge rate from observed conditions where the dry season typically occurs over a 5-month period. Scenario 2 simulates a shorter dry season by reducing the stress period by one month, while Scenario 3 extends the drought one month. Scenario 15 is considered the worst case scenario given the maximum projected climatic conditions of a $3{ }^{\circ} \mathrm{C}$ annual increase in $\mathrm{T}_{\mathrm{m}}$, a $12 \%$ decrease in $\mathrm{P}_{\mathrm{m}}$, and a dry season lasting a month longer.

\section{RESULTS AND DISCUSSION}

\subsection{Soil Tests, Water Balance and Recession Analysis}


Soil profiles show 1-8 $\mathrm{cm}$ of organic material underlain by $40-80 \mathrm{~cm}$ of dark- to mediumbrown, moderately sorted organic-rich soil, with an average root zone depth of $560 \mathrm{~mm}$. Below this lies 0.5 - $1 \mathrm{~m}$ of more porous, slightly aggregated, sandy loam andesol subsoil, grading into poorly sorted, highly weathered, friable andesite and dacite parent material. Soil samples collected in the field were generally composed of 39\% sand, 32\% silt, and $29 \%$ clay, revealing a moderately sorted clay loam to loamy soil.

Table 2. Soil analysis results

\begin{tabular}{|c|c|c|c|c|c|c|c|}
\hline \multicolumn{8}{|c|}{ Soil Samples and Calculations } \\
\hline \multirow[b]{2}{*}{ Depth from surface $(\mathrm{cm})$} & \multirow{2}{*}{$\begin{array}{c}\text { Sample } 1 \\
1-11\end{array}$} & \multirow{2}{*}{$\begin{array}{c}\text { Sample } 2 \\
30-40\end{array}$} & \multicolumn{5}{|c|}{ Permeameter Tests } \\
\hline & & & \multirow[b]{2}{*}{ Borehole } & \multirow[b]{2}{*}{ Trial } & \multirow{2}{*}{$\begin{array}{c}\mathrm{Q} \\
\text { (cc/day) }\end{array}$} & \multirow{2}{*}{$\begin{array}{c}\mathrm{K}_{\text {sat }} \\
\text { (mm/hour) }\end{array}$} & \multirow{2}{*}{$\begin{array}{c}\mathrm{K}_{\mathrm{sat}} \\
\text { (m/day) }\end{array}$} \\
\hline Wt. Jar + Wt. wet & & & & & & & \\
\hline Sample (g) & 733 & 766 & LDS1 & $4 / 18 / 2014$ & 49885 & 11.0 & 0.26 \\
\hline Wt Jar (g) & 37 & 37 & LDS1 & $4 / 20 / 2014$ & 31298 & 6.9 & 0.17 \\
\hline Wt Wet Sample (g) & 696 & 729 & LDS2 & $4 / 23 / 2014$ & 331168 & 29.8 & 0.72 \\
\hline Wt Dry Sample (g) & 567 & 601 & LDS2 & $5 / 21 / 2014$ & 521060 & 33.6 & 0.81 \\
\hline Vol of Soil in Jar $\left(\mathrm{cm}^{3}\right)$ & 419 & 419 & LDS3 & $5 / 21 / 2014$ & 267649 & 36.4 & 0.87 \\
\hline Particle Density $\left(\mathrm{g} / \mathrm{cm}^{3}\right)$ & 2.65 & 2.65 & LDS4 & $5 / 23 / 2014$ & 210011 & 33.3 & 0.80 \\
\hline Bulk Density $\left(\mathrm{g} / \mathrm{cm}^{3}\right)$ & 1.35 & 1.43 & LDS5 & $5 / 25 / 2014$ & 194643 & 19.4 & 0.46 \\
\hline Porosity (\%) & 49.06 & 45.87 & LDS6 & $5 / 25 / 2014$ & 243221 & 18.6 & 0.45 \\
\hline Volumetric Water & & & & & Range & $6.9-36.4$ & $0.17-0.87$ \\
\hline Content (\%) & 30.8 & 30.5 & & & Average & 23.6 & 0.57 \\
\hline Specific Yield (\%) & 16 & 16 & & & & & \\
\hline Soil Field Capacity & 33 & 30 & & & & & \\
\hline
\end{tabular}

Lab test results are shown in Table 2 and reveal a soil porosity around $0.46-0.49$, field capacity of 0.3 , and a specific yield of $16 \%$. The permeameter tests estimate saturated hydraulic conductivity ranging between $0.17-0.87 \mathrm{~m} /$ day, providing an average infiltration rate of $0.57 \mathrm{~m} / \mathrm{day}$, or $24 \mathrm{~mm} /$ hour, for the watershed. $K_{\text {sat }}$ and porosity results suggest a loam soil (Saxton and Rawls, 2006). The field capacity and specific yield values typify other volcanic soil conditions located in tropical climates. Concerning recharge to the aquifer, these results indicate a soil with a decent rate of infiltration that is not too clay-rich to restrict ample recharge, yet has particles small enough and sorted well enough for moderate to high water storage capabilities.

Local and regional weather stations provided an average annual rainfall of $3896 \mathrm{~mm}$ for the watershed, averaging $519 \mathrm{~mm} / \mathrm{month}$ during the wet season and $52 \mathrm{~mm} / \mathrm{month}$ during the dry season. Average monthly temperatures throughout the year ranged from $24.3{ }^{\circ} \mathrm{C}$ to $26.5^{\circ} \mathrm{C}$, with an annual average of $25^{\circ} \mathrm{C}$. The TMWB model calculated an annual actual evapotranspiration of $1218 \mathrm{~mm}$, or $31 \%$ of the annual rainfall. Using the soil infiltration rate and onsite hourly rainfall rates, estimated annual runoff in the catchment area was $591 \mathrm{~mm}$, or $15 \%$ of the annual rainfall. 
Runoff was observed in an ephemeral stream during and shortly after several storms during the middle of the wet season. The estimated annual runoff when subtracted from the annual recharge rate accounted for in the TMWB model provides an effective annual recharge rate of $2.087 \mathrm{~m} /$ year, or $0.005714 \mathrm{~m} /$ day. Figure 9 graphically demonstrates the hydrologic elements affecting recharge throughout the year in the TMWB model.

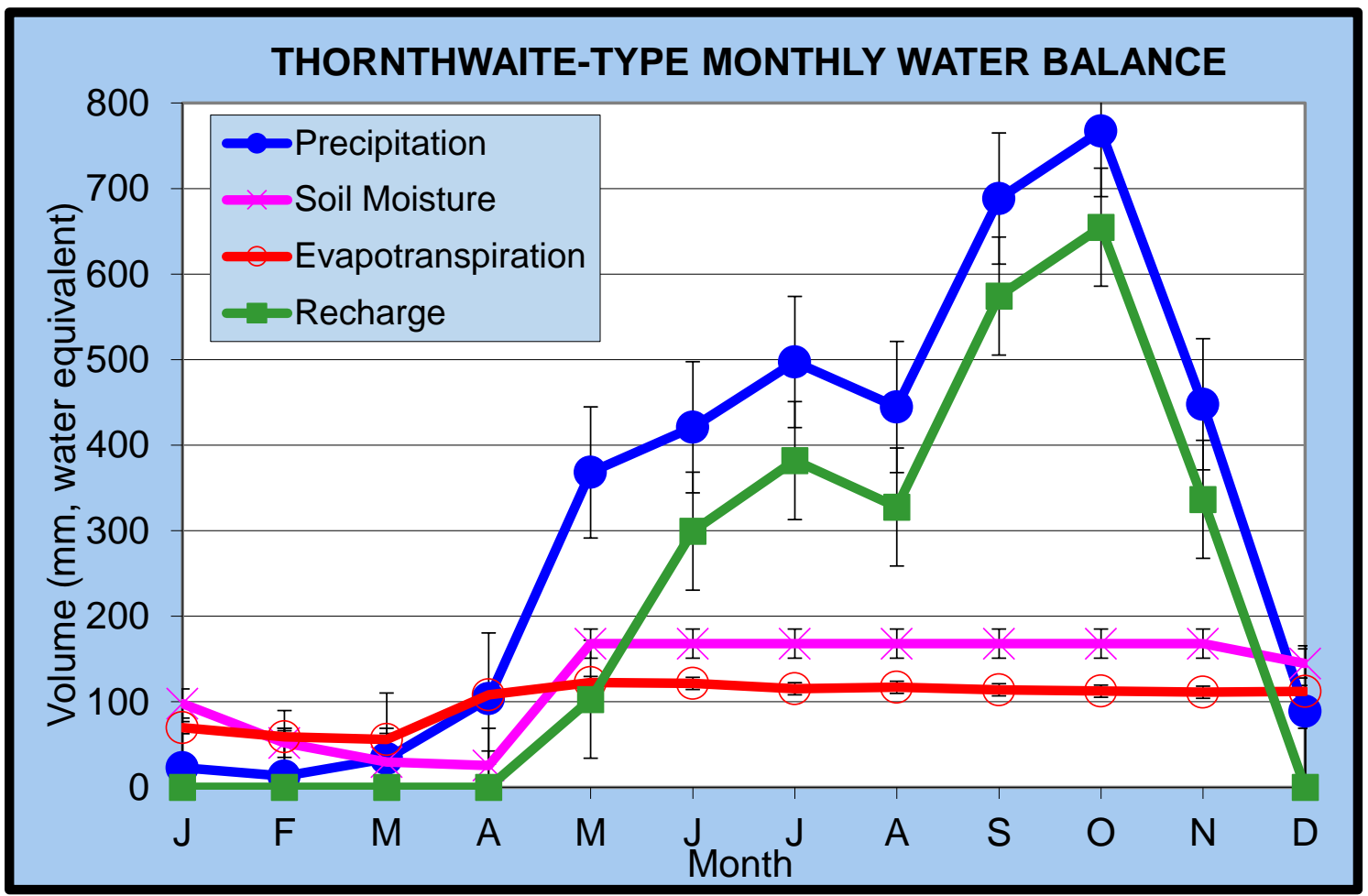

Figure 9. TMWB model graphically illustrating monthly relationships between soil moisture, precipitation, evapotranspiration and recharge in the Candela watershed.

With a recharge rate at $53 \%$ of annual precipitation, this value is relatively high, even for a gently sloping watershed with up to $20 \mathrm{~cm}$ of leaf litter and thick organic soil horizons. Bakundukize et al. (2011) and others suggest the TMWB method can overestimate annual recharge by $15 \%$ or more; therefore this approximation served as a high reference value during model calibration in MODFLOW. The wet season flow observations were used to calibrate recharge during steady-state conditions to $1.928 \mathrm{~m} /$ year, or 0.00528 $\mathrm{m} /$ day, further reducing recharge by $4 \%$.

Combined discharge measured from both springs peaked around $1200 \mathrm{~m}^{3} /$ day immediately after large storm events during the month of September. The end of the wet season in late November saw combined flows around $220.1 \mathrm{~m}^{3} /$ day, which was used as a reference for end-of-wet season values input into MODFLOW. The recession period of the hydrograph shows an asymptotic decrease in flow for roughly 5 months until consistent rainfall began at the end of April (Figure 10). Flows dropped to $100 \mathrm{~m}^{3} /$ day by 
mid-January, $38 \mathrm{~m}^{3} /$ day by early March, and by the end of the dry season in late April, total spring flows averaged around $18.5 \mathrm{~m}^{3} /$ day, a $92 \%$ reduction. The recession analysis provided the starting and ending flow values, as well as the observed recession curve used to calibrate the groundwater flow model.

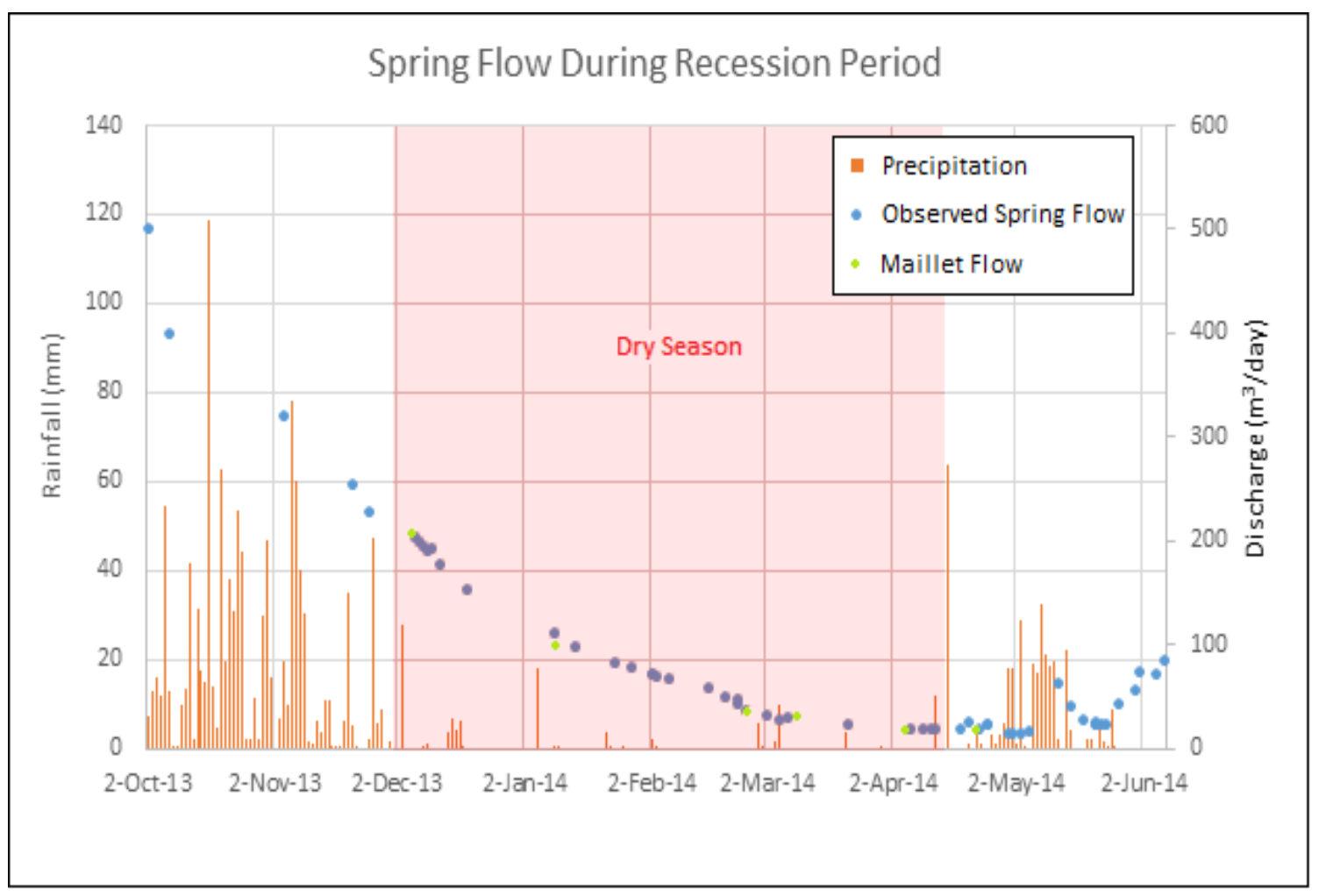

Figure 10. Baseflow recession curve including flow projections from Maillet equation

Figure 10 displays the baseflow calculations using the Maillet equation compared to the observed flows during the recession. Discharge values were accurate to within $11 \%$ of the observed flows, offering a relatively sound method to compare results from the groundwater flow model for both the recession and for forecasting extended drought scenarios.

\subsection{Groundwater Flow Model}

\subsubsection{Model Calibration}

In an attempt to minimize error between the observed and computed dry season flow behavior, storativity $\left(S_{y}\right)$ and hydraulic conductivity $(K)$ parameters were calibrated simultaneously for each model in MODFLOW by trial and error, parameter estimation, and stochastic estimation. Using the automated parameter estimation tool, 11 observed points along the recession curve were entered into the Transient Observation Flow component in the Conceptual Model to calibrate $S_{y}$ and $K$. The majority of the points 
used were from the last 45 days of the recession period, from early March to mid-April, in order to represent the driest conditions.

Calibration consisted not only of reducing flow error but also minimizing grid cell 'flooding' and 'drying'. Cell 'flooding' occurs when the hydraulic head exceeds the elevation of the cell, effectively simulating ground seepage. Some level of flooding was acceptable, especially in topographically low areas, given the interpolation technique used to estimate ground elevations and the approximation nature of the groundwater flow models. Cell 'drying' occurs when the hydraulic gradient elevation is below the cell bottom elevation which restricts recharge to the cell, creating errors and a poor mass balance. Since there is no recharge during the dry season, cell 'drying' that occurs during the dry season stress period is acceptable. Table 3 summarizes the parameters estimated from field measurements and the water budget analysis, as well as the calibrated parameters found in the simulations for Models 1 and 2.

Table 3. MODFLOW calibrations for the Wedge Model (Model 1) and the Draped Model (Model 2)

\begin{tabular}{|c|c|c|}
\hline \multicolumn{3}{|c|}{ Model Calibration Results } \\
\hline \multicolumn{3}{|l|}{ Parameter Estimations } \\
\hline Recharge Rate (m/d) & \multicolumn{2}{|l|}{0.00528} \\
\hline Observed End-of-Wet Season Flow $\left(\mathrm{m}^{3} / \mathrm{d}\right)$ & \multicolumn{2}{|l|}{220.1} \\
\hline Observed End-of-Dry Season Flow (m³/d) & \multicolumn{2}{|l|}{18.5} \\
\hline Drain Conductance Lower Spring $\left(\left(\mathrm{m}^{2} / \mathrm{d}\right) / \mathrm{m}\right)$ & \multicolumn{2}{|l|}{1} \\
\hline Drain Conductance Upper Spring $\left(\left(\mathrm{m}^{2} / \mathrm{d}\right) / \mathrm{m}\right)$ & \multicolumn{2}{|l|}{2} \\
\hline Parameter Calibrations & Model 1 & Model 2 \\
\hline Hydraulic Conductivity (m/d) & 20 & 0.2 \\
\hline Storativity Coefficient $\left(S_{y}\right)$ & 0.04 & 0.3 \\
\hline
\end{tabular}

\subsubsection{Model Performance}

The best fit calibrations for both Model 1 and Model 2 produced flows for the end of the wet season of $220.1 \mathrm{~m}^{3} / \mathrm{d}$, while computed flows for the end-of-dry season were 16.0 $\mathrm{m}^{3} / \mathrm{d}$ for Model 1 and $28.1 \mathrm{~m}^{3} / \mathrm{d}$ for Model 2. Overall, Model 1 simulated flows to within $12 \%$ of the observed flow throughout the recession period and to within $1 \%$ during the last 45 days of the recession (Figure 11). Model 2 yielded flows that had a 37\% error overall and $9 \%$ error during the last 45 days of the recession period.

For both models, the steep topographic gradient exacerbated cell "flooding", where the slope of the layer was too steep to simulate the hydraulic gradient properly throughout seasonal fluctuations and with only two outlets. Under the storativity and hydraulic 
conductivity conditions required for the temporal demands of the simulation, stored water would "pool up" in the lowest grid cells in the models.

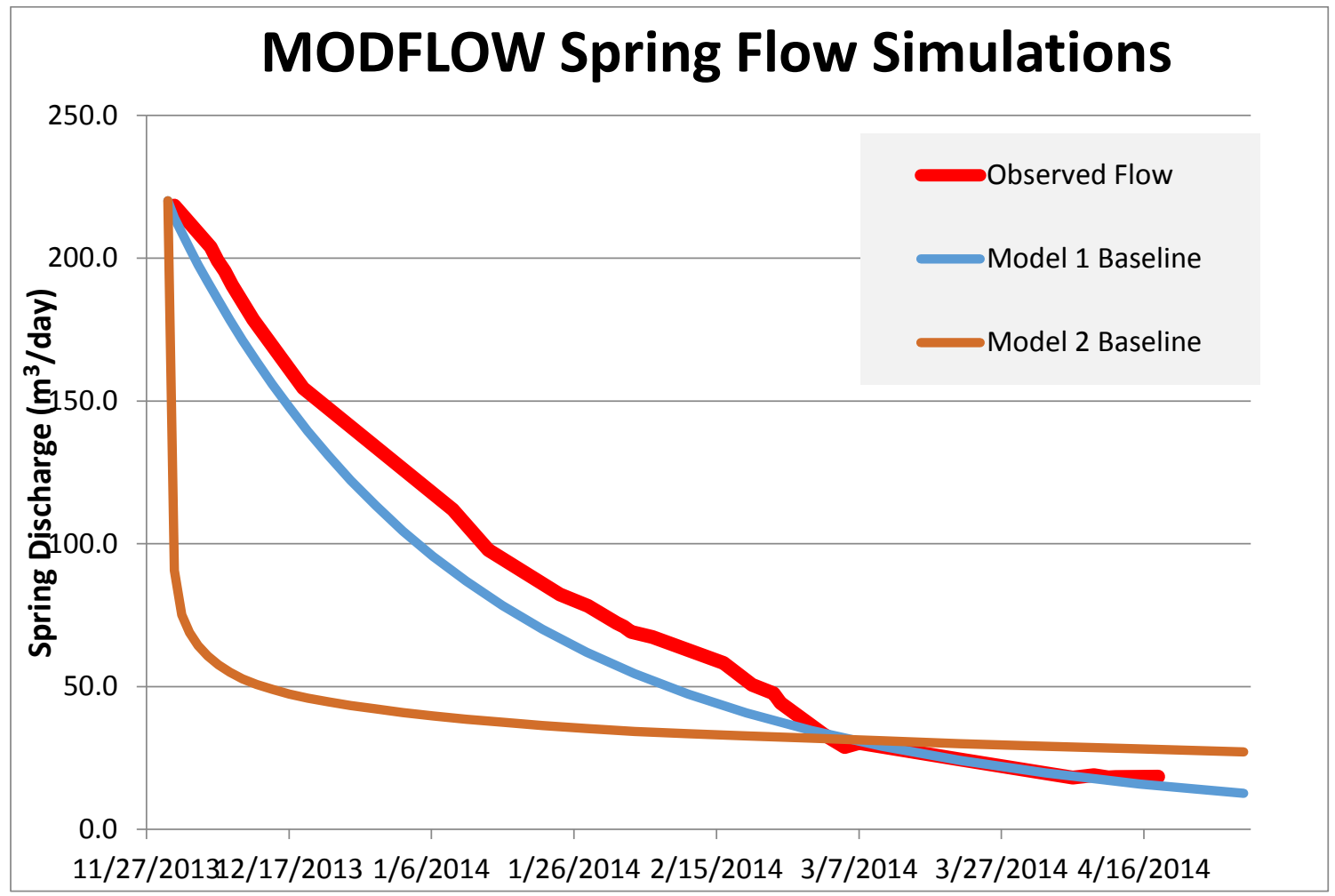

Figure 11. MODFLOW model simulations compared to the Observed Flow

The simulated flows for Model 2 during the recession were $37 \%$ less than the observed flows overall; roughly $70 \%$ less in January, 50\% less in February, and within 5\% error during early March; and over 50\% higher in April. As shown in Figure 11, computed flows were reduced immediately from $220 \mathrm{~m}^{3} /$ day to $75 \mathrm{~m}^{3} /$ day in the first day and soon leveled off to a sustainable flow that would minimize residual error for the majority of calibration points in the last 45 days. Model 2 was highly sensitive to parameter adjustments and often failed to converge on a solution for multiple iterations during calibration. Figure 12A illustrates extensive cell flooding in the early time steps, followed by complete cell drying of the upper reaches displayed in Figure 12B. A hydraulic conductivity as low as $0.2 \mathrm{~m} / \mathrm{d}$ was required to keep the hydraulic gradient steep enough to stay within the grid cell and reduce cell drying and flooding. Any higher values would force the majority of cells in the upper reaches of the watershed to begin the simulation dry and cause more flooding in the lower cells. The maximum allowable specific yield of 0.3 , equal to the effective porosity, used in Model 2 was critical in maximizing water storage in order to sufficiently supply the water demand throughout the stress period. Overall, the simulation of processes and predictions of discharge in Model 2 were unrealistic and outside the range of acceptable observational error. 


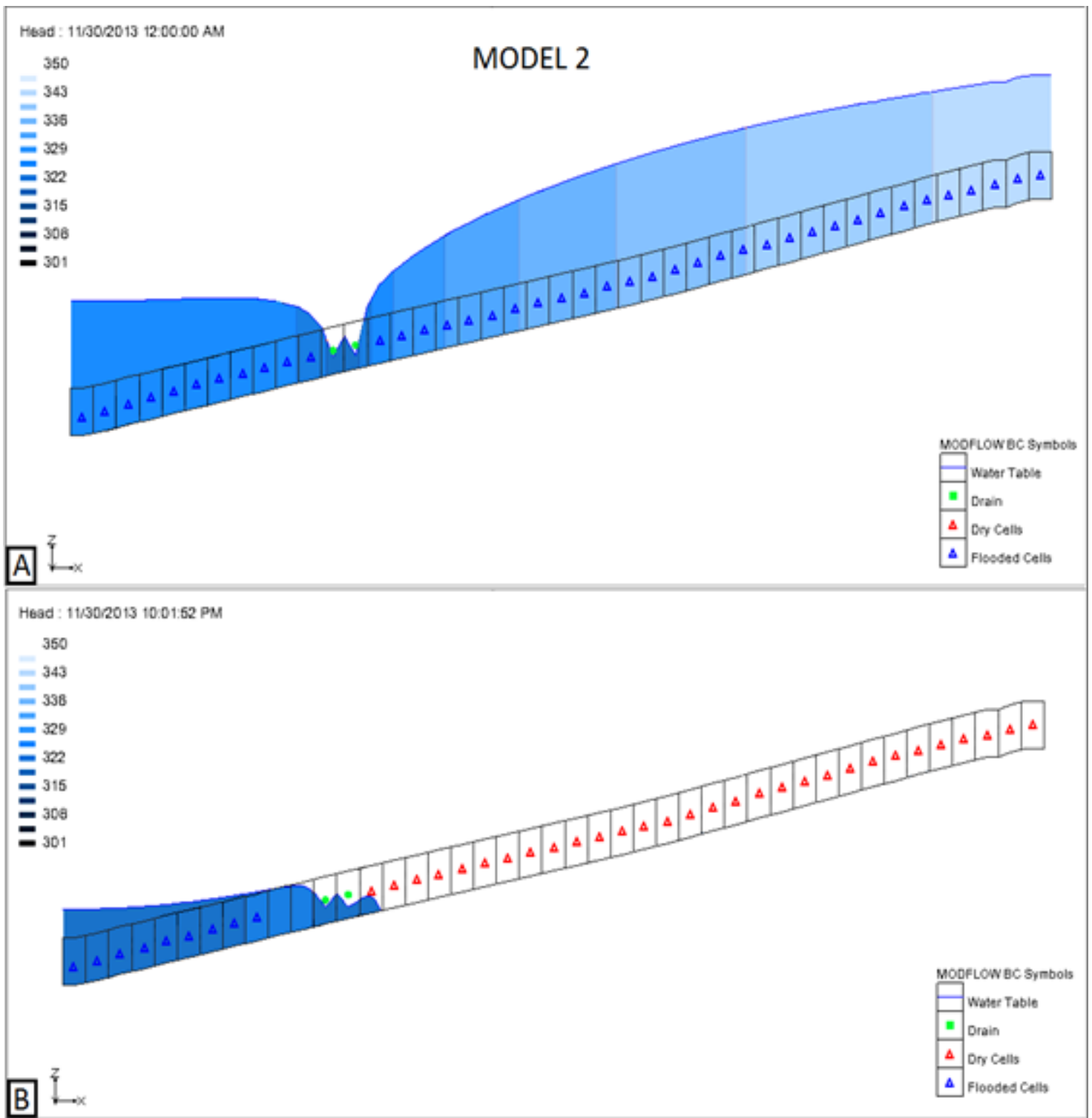

Figure 12. A) Cross sectional view of Model 2 in MODFLOW exhibiting initial cell flooding and B) Cell drying as time progressed

The computed flows in Model 1 were simulated to be $11 \%$ less than the observed flows overall, roughly $20 \%$ less in January and February, and within 3\% error during March and April (Figure 11). The hydrologic parameters seem best calibrated to simulate the observed flow behavior during the recession period between March $7^{\text {th }}$ and April $15^{\text {th }}$. Hydraulic conductivity was an order of magnitude higher in Model 1 than in Model 2 and $K_{\text {sat }}$ measured in the field. This allowed for higher flow through the aquifer contributing to Upper Spring running dry after 3 months, which caused the remaining flow to discharge out of Lower Spring. Conversely, in the field the discharge from Upper Spring persisted longer, behaving more asymptotically than discharge from Lower Spring, 
emphasizing the potential shortcomings in assuming an isotropic and homogenous aquifer.

Model 1 was less sensitive to fluctuations in parameter values when converging on a solution and had less cell flooding or drying. This was due in part to a larger grid cell thickness which allowed for more flexibility in water table flux. Figure 13 shows a range of results for hydraulic conductivity values between $15-25 \mathrm{~m} / \mathrm{d}$ and storativity values between 0.04-0.05 that accommodated various flow regimes found throughout the recession.

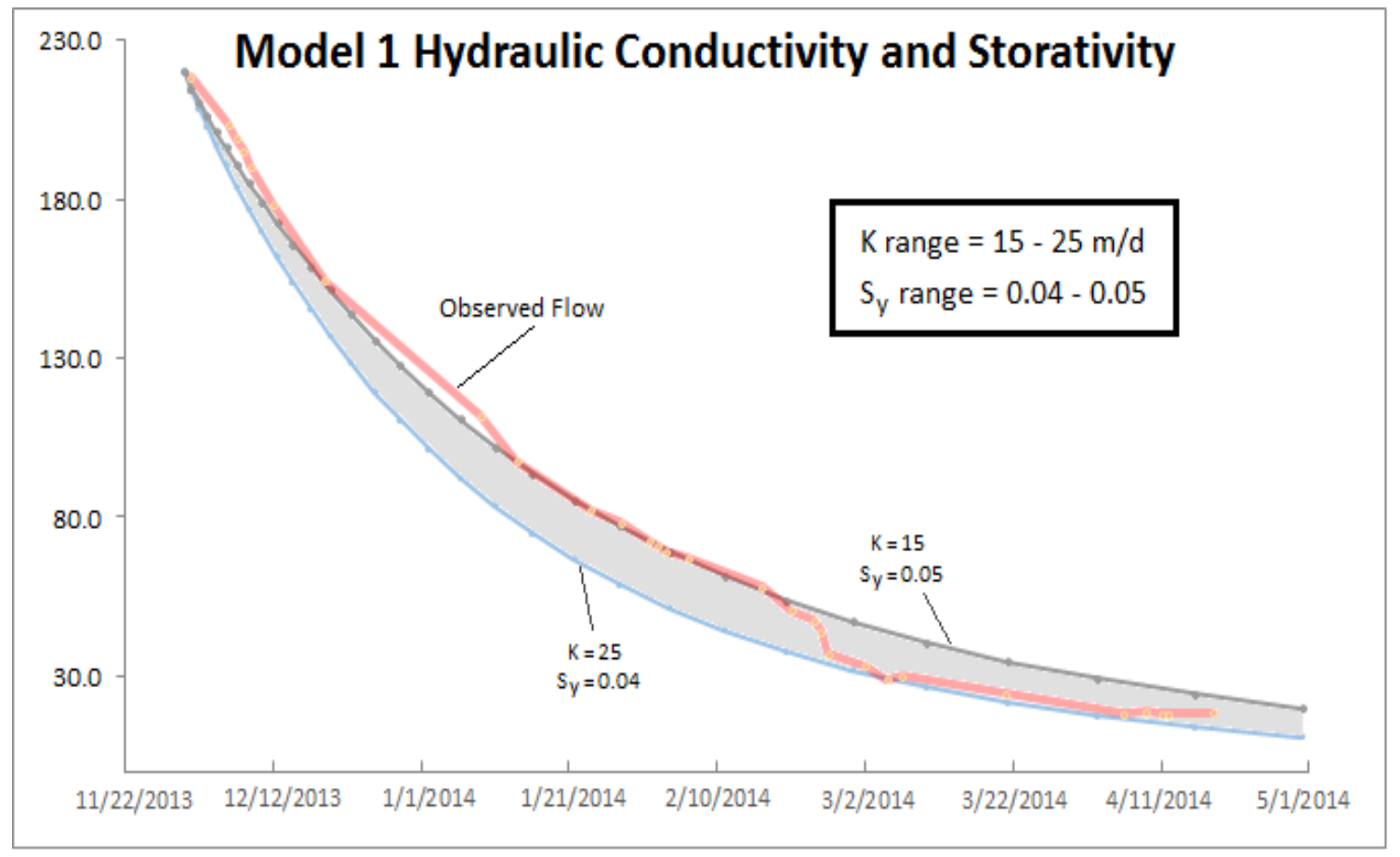

Figure 13. Shaded area represents the range of flows based on ranges of hydrologic parameters in Model 1

In this model, higher storativity values yielded more available water contributing to higher flows overall throughout the season, and flow in the early months of the dry season was simulated more effectively. With more available water in the system, a reduction in $K$ was required to retard water movement in order to decrease the slope of the recession curve to match late season flow demands and to quell additional cell flooding. Overall, Model 1 performed considerably better in reducing residual flow errors and cell flooding and eliminating cell 'drying' altogether, and proved to be a more resilient model than Model 2.

Models 1 and 2 are differentiated in part by their physical dimensions and storativity parameters, two factors that define aquifer storage. Using saturated thicknesses found above the Lower Spring drain elevation, the volume of water available in Model 1 was roughly $11,000 \mathrm{~m}^{3}$, twice that of Model 2 which was nearly $5,000 \mathrm{~m}^{3}$. Since unsaturated 
flow processes were not accounted for in these models, only saturated flow elements contribute to the water availability. Hunt et al. (2008) found that when modeling aquifers with thick unsaturated zones, the volume of recharge was properly simulated but errors occurred in the timing of recharge given the long term percolation nature of unsaturated flow. Excluding flow and potential long term recharge influences from the unsaturated zone could substantially inhibit the quantity and timing of available water. Overall, the model results under these configurations suggest that aquifer thickness is an integral control on simulating drain outflows in steep terrain and on reducing systemic errors.

\subsubsection{Climate Scenarios}

Table 4 presents results from the climate change simulations revealing simulated discharges for each scenario and the percent change in flow relative to the observed flow conditions. The "Baseline" scenario represents the calibrated model simulations for each model, and serves as a reference scenario to compare the various climate change scenarios. These scenarios differed in either the recharge rate by altering rainfall and/or temperature, in the length of recession period, or in a combination of both.

Table 4. Climate change simulation results

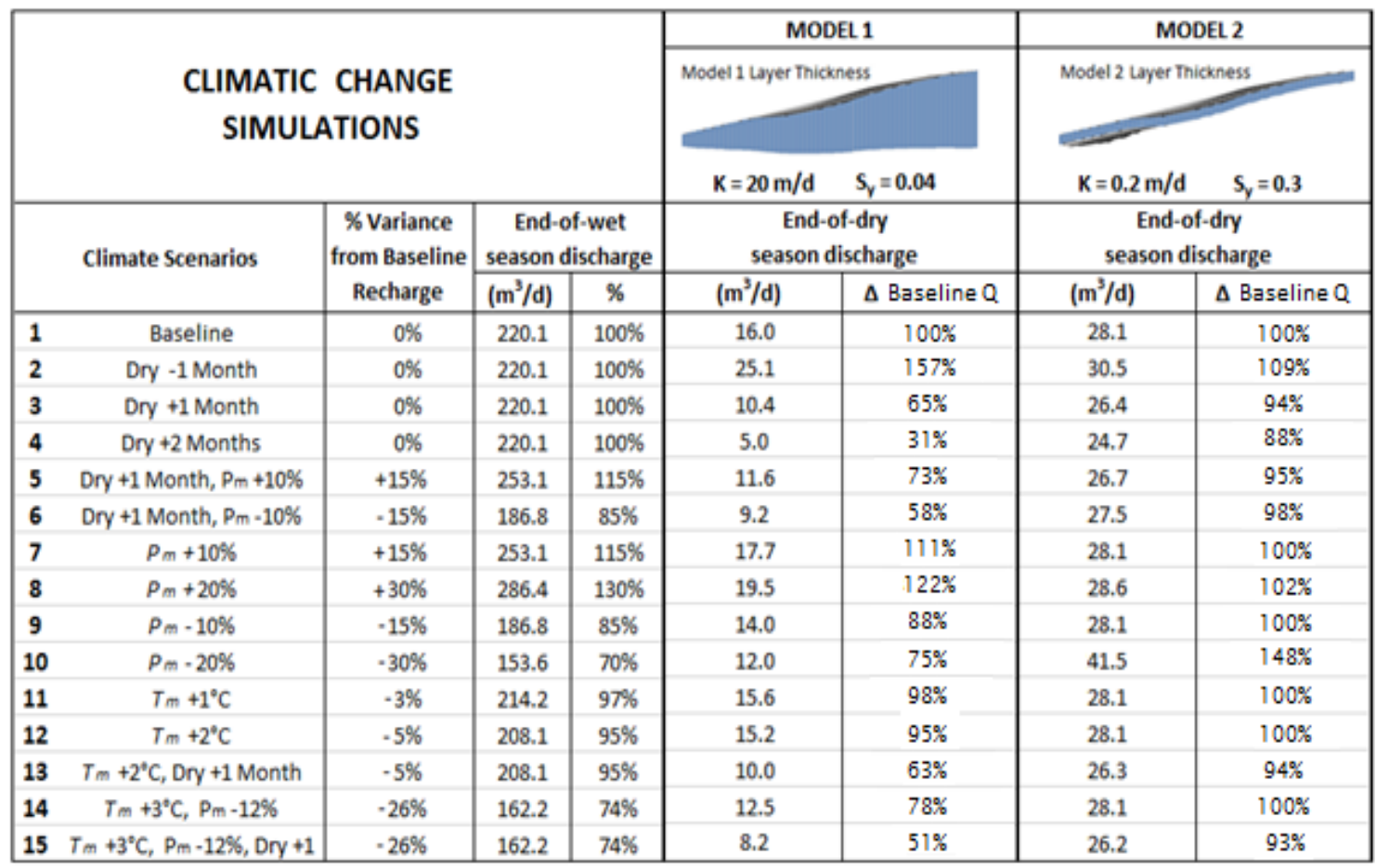

Column 2 in Table 4 shows the difference in the applied recharge rates derived from variable climate conditions. In Scenario 8, a $20 \%$ increase in monthly precipitation generates $30 \%$ more recharge, resulting in a 5\% increase in flow from the observed value for the end of the dry season in Model 1 and a 55\% increase for the same in Model 2. The 
$3{ }^{\circ} \mathrm{C}$ monthly temperature increase and $12 \%$ decrease in monthly precipitation outlined in Scenario 14 caused a $26 \%$ decrease in recharge rate, resulting in just $74 \%$ of the observed flow at the beginning of the simulation, and a $32 \%$ reduction in the end-of-dry season flows in Model 1. Scenario 14 conditions had no effect on flow behavior in Model 2.

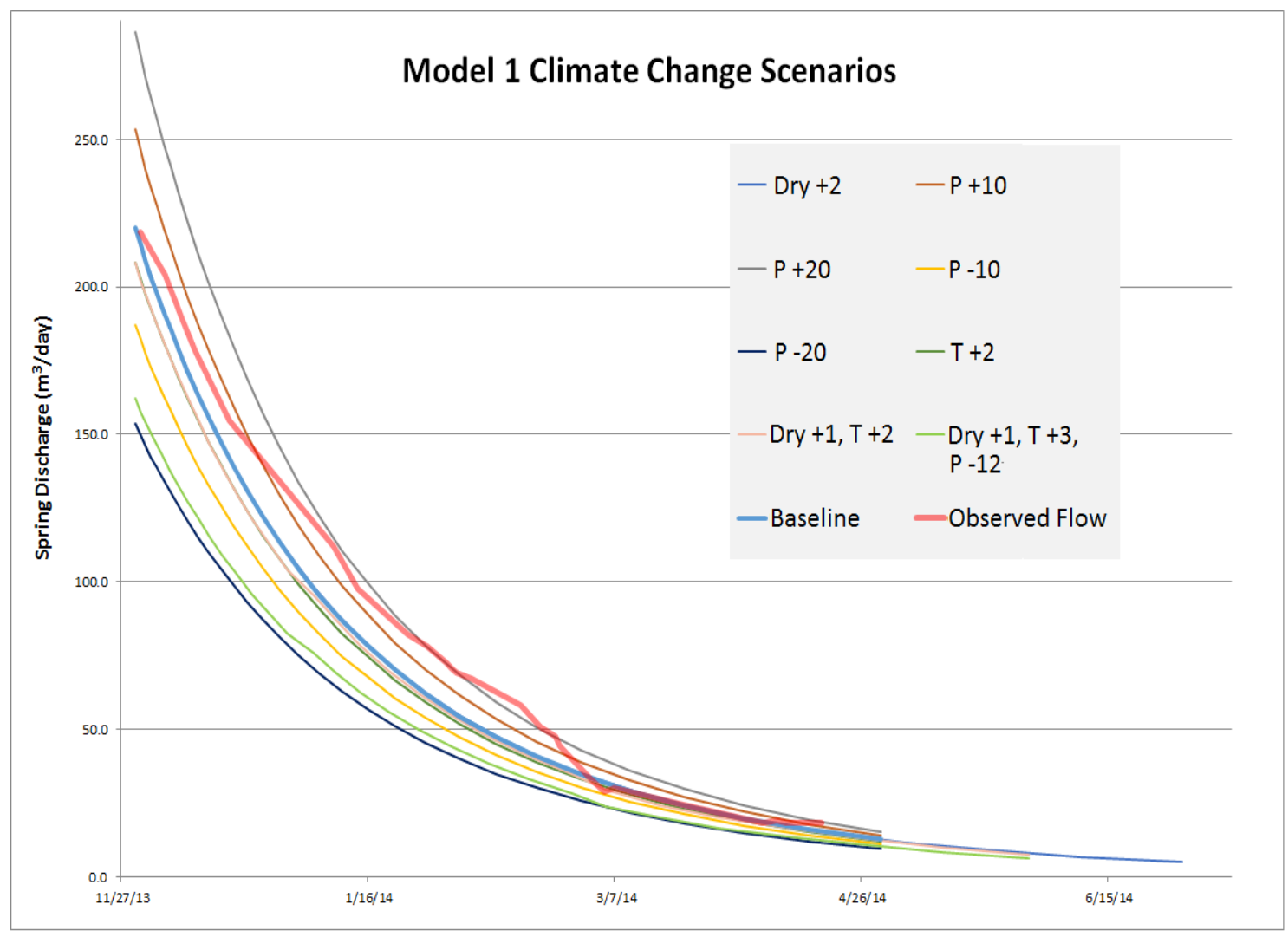

Figure 14. Selected climate change simulation results for Model 1

Shown in Figure 14, Model 1 results validated the expected flow response trends to corresponding adjustments in recharge rate and drought period length. Temperature rise and less rainfall caused flows to decrease, while higher rainfall produced higher flows throughout the simulations. Each degree Celsius increase caused a $2 \%$ reduction in flows, while each percent increase or decrease in annual precipitation yielded that same percent change in flow response. The model confirms that the greatest effect in spring yield is persistent drought, as anticipated. If the worst case scenario according to the IPCC represented in Scenario 15 occurred, spring discharge would decrease by over $50 \%$. When comparing a conventional approach to baseflow recession analysis using the exponential function developed by Maillet, Model 1 yielded comparable discharges under extended drought conditions. After an additional month of drought, spring flow was 1.5\% lower in Model 1 than those found using the Maillet approach, and 13\% lower after two months. This suggests that the baseflow recession curve observed in the field can 
generally be expressed by this exponential equation as well as by groundwater flow model.

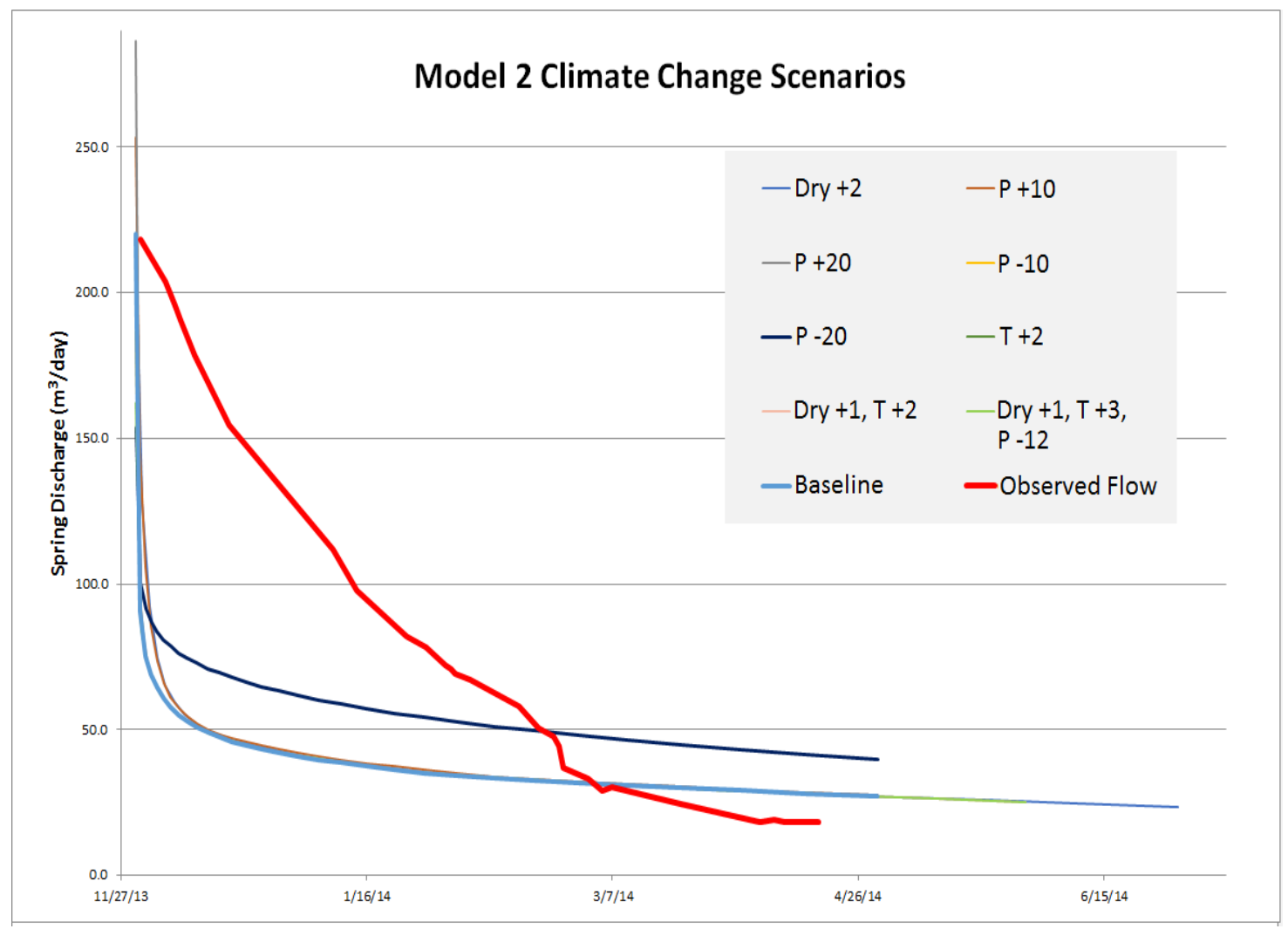

Figure 15. Selected climate change simulation results for Model 2

Figure 15 illustrates the flow responses to climate change scenarios in Model 2 showing the precision of error compared to the Baseline scenario. The degree of change in flow trends differs significantly between the two models. Model 1 behaves more resiliently than Model 2 by simulating sustained spring discharge under a range of environmental conditions. The variability between each simulation in Model 2 was very low with the exception of a $20 \%$ rainfall reduction in which the flow was overestimated. Using Model 2 to forecast differing climatic scenarios proved ineffective due to its inaccuracy in adjusting flow response and its fragility to parameter modifications.

A warmer climate allows more moisture capacity of the air which produces more intense rainfall events and higher runoff yields (Karl et al., 2009). Adjusting potential runoff was not factored into the recharge adjustments for any scenarios. Overall, these models oversimplify the potential changes in water availability due to a shifting environment, yet offer a general idea of how spring flows may behave in the watershed. Water managers in Candela can use these flow estimates to help prepare for the future of uncharacteristic flows given a changing climate. They can add storage by building water tanks, reduce 
water waste by fixing leaks and closing the taps when not in use, and increase recharge by not practicing slash-and-burn agriculture in the watershed.

\section{CONCLUSIONS}

A variety of techniques were used in this research to better understand the hydrologic processes controlling spring flow that supplies domestic water to the indigenous community of Candela, located in the tropical mountain region of western Panama. Stark climatic differences in rainfall throughout the year are aligned with seasonal fluctuations in water output at the springs suggesting a proportional commonality between the two. This study quantified hydrologic system components, estimated the water budget in the catchment area and developed groundwater flow models using plausible aquifer characteristics to simulate flows at the springs.

The volcanic soil types observed in the watershed ranged from clay loam to sandy loam and had an average infiltration rate of $24 \mathrm{~mm}$ /day and a soil field capacity of 0.30 . Spring flows demonstrated high seasonal variability yet revealed distinct baseflow behavior during the recession period. Of the approximately $4 \mathrm{~m}$ of precipitation occurring on average in the watershed, the water balance model estimated $1.2 \mathrm{~m}$ was lost to evapotranspiration, $0.5 \mathrm{~m}$ ended up as runoff during intense storm events, and around $2 \mathrm{~m}$ percolated into the aquifer as recharge. Model 1 has a thicker wedge-shaped aquifer that simulated observed spring flows with more accuracy than Model 2 which has a much thinner, lens-shaped aquifer. The greater aquifer storage available in Model 1 is attributed to more accurate simulations than those in Model 2. Adjustments in temperature, precipitation and length of dry season significantly impacted spring flows in Model 1, especially for rainfall reductions and extended periods of drought. Forecasts of drought from the conventional baseflow recession analyses also largely resemble numerical approximations from Model 1.

As there is an ample supply of low intensity rainfall to the watershed, spring discharge is sustained throughout the long dry season by a combination of receptive soil and aquifer material, and sufficient aquifer storage volume and retention. The results suggest that the saturated substratum has large enough interstitial storage capacity to store a substantial amount of water, yet the media is fine enough or flow paths tortuous enough to slowly release water over time. Collecting basic watershed information from the field and examining it using analytical and numerical models can reveal quantifiable controls on water availability from the springs. The data collection and methods used in this research 
could similarly be reproduced in other watersheds and may be considered an appropriate technology in water system design and management.

\section{FUTURE WORK}

Given the simplified nature of this project using minimal data collection instruments, a broader analysis could have been performed in this watershed. Installing a continuous flow measuring device such as a variable-flow totalizer would enhance flow data precision and exact timing of spring flow response to rainfall events. This would offer sufficient data for several other analyses to be done to better decipher aquifer properties from spring flow behavior. Drilling a well into the aquifer would have provided valuable information about aquifer composition and thickness as well as reveal the relationship between the potentiometric surface and spring discharge throughout the seasons.

As unsaturated flow was unaccounted for in the groundwater flow models, large assumptions regarding effective aquifer recharge were made. Applying the Unsaturated Zone Flow package in GMS MODFLOW could better simulate recharge processes that directly affect the timing and amount of available water supply at the springs. The necessary input data for this package include: infiltration rate, evapotranspiration extinction depth, evapotranspiration demand rate, and extinction water content. Constructing more groundwater flow models with variable aquifer geometries would allow for a better analysis of the storage capabilities of each aquifer.

\section{REFERENCES}

Bakundukize C., Van Camp M., Walraevens K. 2011. Estimation of groundwater recharge in Bugesera region (Burundi) using soil moisture budget approach. Geologica Belgica. 14(1-2). p.85-102

Bryan K. 1919. Classification of springs. The Journal of Geology. 27(7):522-561.

Dewandel B, Lachassagne P, Bakalowicz M, Weng Ph, Al-Malki A. 2003. Evaluation of aquifer

thickness by analysing recession hydrographs. Application to the Oman ophiolite hardrock 
aquifer. J Hydrol 274: 248-269.

Dingman, Lawrence S. 2002. Physical Hydrology; 2nd Edition. New Jersey: Prentice Hall Inc.

Elrick, D. E., Reynolds, W. D., 1992. Methods for analysing constant-head well permeameter data. Soil Science Society of America Journal. 56(1), 320-323 p.

Etesa. November 2014. "Hydrometeorology: Historical Climate Data." http://www.hidromet.com.pa/clima_historicos.php accessed November 2014

EMS-I. February 2015. "Groundwater Modeling System Introduction". <www.emsi.com> accessed: February 2015

Hall, F.R., 1968. Base flow recessions: a review. Water Resource. Res. 4 (5), 973-983.

Hamon, W.R., 1961, Estimating potential evapotranspiration: Journal of the Hydraulics Division, Proceedings of the American Society of Civil Engineers, v. 87, p. 107-120.

Harbaugh, A.W., and McDonald, M.G., 1996a. User's documentation for MODFLOW96, an update to the U.S. Geological Survey modular finite-difference ground-water flow model: U.S. Geological Survey Open-File Report 96-485, 56 p.

Harbaugh Arlen W. and Banta Edward R., and Hill, Mary C. and McDonald, Michael G. 2000. "MODFLOW - 2000, The U.S. Geological Survey Modular Ground-Water Model”. U. S. Geological Survey. Report.00-92

Harmon, R. S. 2005. The Geological Development of Panama. Water Science and Technology Library, 52, 45-64.

Healy, R. W., Winter, T. C., LaBaugh, J. W. and Franke, O. L. 2007. Water budgets: foundations for effective water-resources and environmental management. US Geological Survey Circular 1308.

Hewlett, J.D. and Hibbert, A.R. 1963. Moisture and energy conditions within a sloping soil mass during drainage. Journal of Geophysical Research 68, 1081-87. 
Hunt, R.J., D.E. Prudic, J.F. Walker, and M.P. Anderson. 2008. Importance of unsaturated zone flow for simulating recharge in a humid climate. Ground Water 46(4):551-560.

IPCC (Intergovernmental Panel on Climate Change) (2001) Climate change 2001: the scientific basis. Contribution of Working Group I to the Third Assessment Report of the Intergovernmental Panel on Climate Change. www.ipcc.ch

Johnson, A., Prill, R., Morris, D. 1963. Specific yield - column drainage and centrifuge moisture content. US Geol Surv Water-Supply Paper 1662-A, 60 pp.

Karl, T. R., J. T. Melillo, and T. C. Peterson, 2009: Global Climate Change Impacts in the United States. T.R. Karl, J.T. Melillo, and T.C. Peterson, Eds. Cambridge University Press, $189 \mathrm{p}$.

Kresic, N. 1997. "Quantitative Solutions in Hydrogeology and Groundwater Modeling," CRC Press, Lewis Publishers, New York, 461p.

Kresic, N. and Stevanovic, Z. 2010. Groundwater hydrology of springs, ButterworthHeinemann, Oxford, 573p.

Lu, J., Sun, G., McNulty, S.G., Amatya, D.M., 2005. A comparison of six potential evapotranspiration methods for regional use in the southeastern United States. Journal of the American Water Resources Association 41 (3), 621-633.

Maillet, E. 1905. Essais d'hydraulique souterraine et fluviale. Librairie Sci., A. Hermann, Paris, 218pp.

Mather, J.R., 1978. The climatic water balance in environmental analysis: Lexington, Mass., D.C. Heath and Company, 239 p.

McDonald, M.G., and Harbaugh, A.W., 1988. A modular three-dimensional finitedifference ground-water flow model: U.S. Geological Survey Techniques of WaterResources Investigations, book 6, chap. A1, 586 p.

Milford, Murray H. 2010. Introduction to Soils and Soil Science Laboratory Exercises; $4^{\text {th }}$ Edition. Kendall/Hunt Publishing Company, Dubuque, Iowa. 
Reynolds, W.D., Elrick, D.E., Topp, G.C., 1983. A reexamination of the constant head well permeameter method for measuring saturated hydraulic conductivity above the water table. Soil Sci. 136, 250-268.

Romano, C.G., E.O. Frind, and D.L. Rudolph. 1999. Significance of unsaturated flow and seepage faces in the simulation of steady-state subsurface flow. Ground Water 34, no.4: $625-632$.

Saxton, K.E. and Rawls, W.J. 2006. Soil water characteristic estimates by texture and organic matter for hydrologic solutions. Soil Science Society of America Journal, 70, 1569-1578.

Sherrod, D.R., Vallance, J.W., Espinosa, A.T., and McGeehin. J.P. 2007. Volcán BarúEruptive History and Volcano-Hazards Assessment: U.S. Geological Survey Open-File Report 2007-1401.

Shonsey CW. 2009. Quantifying Available Water at the Village Level: A Case Study of Horongo, Mali, West Africa. M.S. Report. Houghton, MI: Michigan Technological University.

Stephens, D. B., Neuman, S. P., 1982a. Vadose zone permeability tests: steady-state results. Journal Hydraulics Division, American Society of Civil Engineers. 108(HY5), 640-659 p.

Stephens, D. B., Neuman, S. P., 1982b. Vadose zone permeability tests: unsteady flow. Journal Hydraulics Division, American Society of Civil Engineers. 108(HY5), 660-677 p.

Thein, S.J. 1979. A Flow Diagram for Teaching Texture-by-feel Analysis. Journal of Agronomic Education. 8:54-55.

Thornthwaite CW. 1948. An approach toward a rational classification of climate. Geographical Review. 38(1):55-94.

World Bank. April 2011. "Climate Risk and Adaptation Country Profile: Panama." http://sdwebx.worldbank.org/climateportalb/doc/GFDRRCountryProfiles/wb_gfdrr_clim ate_change_country profile_for_PAN.pdf accessed: November 2015 
Young, Philip D. and John R. Bort. "The Ngöbe of Western Panama." in Susan C. Stonich (ed.) Endangered Peoples of Latin America: Struggles to Survive and Thrive. Westport: Greenwood, 2001.Zangar, C. N., 1953. Theory and Problems of Water Percolation. Engineering Monograph No. 8. United States Bureau of Reclamation, Denver, COLO. 69-71 p. 


\section{APPENDICIES}

\section{Appendix A - Soil Data}

\begin{tabular}{|c|c|c|c|c|c|c|}
\hline \multicolumn{7}{|l|}{ Soil Profiles } \\
\hline \multicolumn{7}{|c|}{ Candela, Panama } \\
\hline \multicolumn{7}{|l|}{$3 / 14$} \\
\hline \multicolumn{7}{|l|}{ LDS1 } \\
\hline depth (in) & Depth (cm) & texture & color & organic & homogeneity & Notes \\
\hline 0 to 2 & $0-4$ & leaf litter & & & & \\
\hline 3 to 5 & $5--12$ & clay loam & dark brown & aves, branches, roo & $100 \%$ soils & \\
\hline 6 to 10 & $13-25$ & clay loam & dark brown & branches, roots & & \\
\hline 11 to 15 & $26-38$ & sandy clay loam & chocolate brown & roots & $10 \%$ clasts $<1 / 2$ in & \\
\hline 16 to 20 & $39-50$ & clay loam & locolate tannish brou & roots & $25 \%$ clasts $<1$ in & \\
\hline 21 to 22 & $51-56$ & sandy clay loam & lighter brown & roots & $30 \%$ clasts $<1$ in & \\
\hline 23 to 25 & $57-64$ & sandy clay loam & tannish brown & & $30 \%$ clasts $<2$ in & \\
\hline 26 to 30 & $65-76$ & sandy loam & tannish brown & & $35 \%$ clasts $<2$ in & fe oxidation \\
\hline \multirow[t]{2}{*}{31 to 33} & $77-84$ & sandy loam & reddish tan brown & & $50 \%$ clasts $<3$ in & fe-rich clasts, \\
\hline & & & & & & oxidation \\
\hline \multicolumn{7}{|l|}{ LDS2 } \\
\hline depth (in) & Depth (cm) & texture & color & organic & homogeneity & Notes \\
\hline 0 to 3 & $0-7$ & leaf litter & & & & \\
\hline 4 to 5 & $8--12$ & clay loam & dark brown & aves, branches, roo & $10 \%$ & \\
\hline 6 to 10 & $13-25$ & sandy clay loam & brown & roots & $25 \%$ clasts $<1 / 2$ in & \\
\hline 11 to 15 & $26-38$ & sandy clay loam & brownish grey & roots & $40 \%$ clasts $<2$ in & decomp andesite \\
\hline 16 to 20 & $39-50$ & sandy loam & light brown, grey & & $50 \%$ & purple and grey \\
\hline 21 to 24 & $51-61$ & sandy loam & light brown, grey & & $50 \%$ & \\
\hline \multicolumn{7}{|l|}{ LDS3 } \\
\hline depth (in) & Depth (cm) & texture & color & organic & homogeneity & Notes \\
\hline 0 to 5 & $0-12$ & silty clay & dark brown & leaves, roots & $20 \%$ rocks & \\
\hline 6 to 10 & $13-25$ & sandy clay loam & brown & roots & $25 \%$ rocks & \\
\hline 11 to 15 & $26-38$ & sandy clay loam & light brown & roots & $50 \%$ coarse, clay & \\
\hline 16 to 19 & $39-48$ & sandy loam & $\tan$ & none & $80 \%$ rock & \\
\hline bedrock & & andesite & purplish grey & & porphiritic & \\
\hline \multicolumn{7}{|l|}{ LDS4 } \\
\hline depth (in) & Depth (cm) & texture & color & organic & homogeneity & Notes \\
\hline 0 to 2 & $0-5$ & & leaf litter & $100 \%$ & & \\
\hline 3 to 7 & $6--18$ & clay loam & dark brown & roots, bugs & well & \\
\hline 8 to 13 & $19-33$ & sandy clay loam & brown & roots & $30 \%$ clasts & \\
\hline 14 to 22 & $34-56$ & sandy loam & light brown & roots & $40 \%$ clasts & \\
\hline
\end{tabular}




\begin{tabular}{|c|c|c|c|}
\hline \multicolumn{4}{|c|}{ Specific Yield (\%) } \\
\hline Material & Maximum & Minimum & Average \\
\hline Coarse gravel & 26 & 12 & 22 \\
\hline Medium gravel & 26 & 13 & 23 \\
\hline Fine gravel & 35 & 21 & 25 \\
\hline Gravelly sand & 35 & 20 & 25 \\
\hline Coarse sand & 35 & 20 & 27 \\
\hline Medium sand & 32 & 15 & 26 \\
\hline Fine sand & 28 & 10 & 21 \\
\hline Silt & 19 & 3 & 18 \\
\hline Sandy clay & 12 & 3 & 7 \\
\hline Clay & 5 & 0 & 2 \\
\hline (Johnson (: & 57) as quot & d by C.W. & tter 2) \\
\hline
\end{tabular}

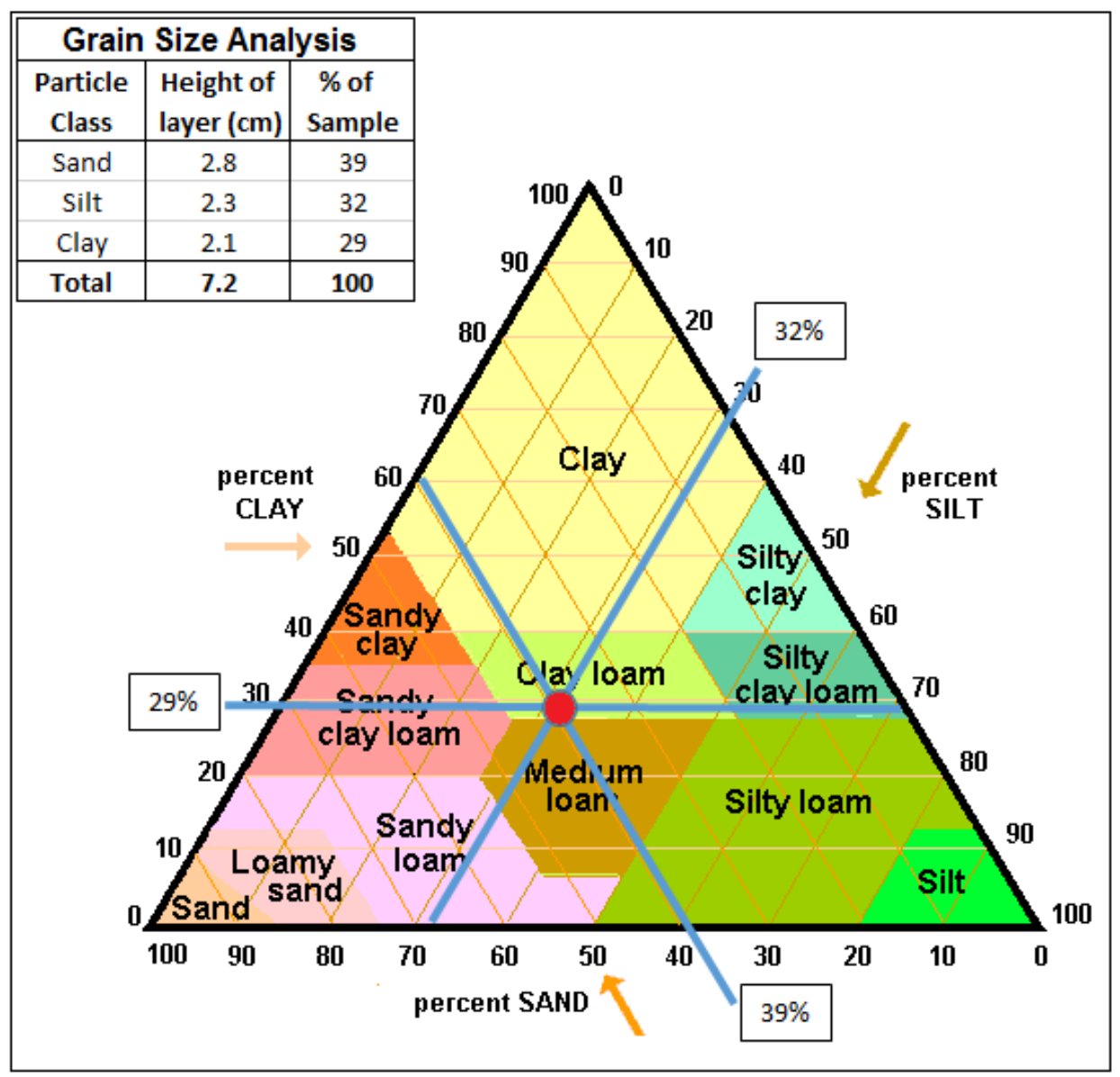




\begin{tabular}{|l|c|c|c|c|c|c|}
\hline & \multicolumn{2}{|c|}{ (Saxton and Rawls 2005) $)^{1}$} & \multicolumn{2}{c|}{ (Rawls et al. 1998) } & \multicolumn{2}{c|}{ (Clapp and Hornberger 1978) } \\
\hline $\begin{array}{c}\text { USDA Soil Textural } \\
\text { Class }\end{array}$ & $\begin{array}{c}\mathrm{K} \text { ( } \\
(\mathrm{ft} / \mathrm{h})\end{array}$ & $\begin{array}{c}\text { Porosity } \\
\left(\mathrm{m}^{3} / \mathrm{m}^{3}\right)\end{array}$ & $\begin{array}{c}\mathrm{K}_{\text {sat }} \\
(\mathrm{ft} / \mathrm{h})\end{array}$ & $\begin{array}{c}\text { Porosity } \\
\left(\mathrm{m}^{3} / \mathrm{m}^{3}\right)\end{array}$ & $\begin{array}{c}\mathrm{K}_{\text {sat }} \\
(\mathrm{ft} / \mathrm{h})\end{array}$ & $\begin{array}{c}\text { Porosity } \\
\left(\mathrm{m}^{3} / \mathrm{m}^{3}\right)\end{array}$ \\
\hline Sand & $0.5091-0.3058$ & $0.48-0.46$ & $0.5965-0.3000$ & $0.44-0.39$ & 0.9732 & 0.40 \\
\hline Loamy Sand & $0.4464-0.1638$ & $0.47-0.44$ & $0.4039-0.1358$ & $0.45-0.37$ & 0.4783 & 0.44 \\
\hline Sandy Loam & $0.3553-0.0744$ & $0.47-0.42$ & $0.1831-0.0425$ & $0.47-0.37$ & 0.1453 & 0.44 \\
\hline Loam & $0.0271-0.1538$ & $0.48-0.46$ & $0.0130-0.0201$ & $0.47-0.39$ & 0.0331 & 0.45 \\
\hline Silt Loam & $0.0402-0.2126$ & $0.48-0.46$ & $0.0472-0.0106$ & $0.49-0.39$ & 0.0083 & 0.49 \\
\hline Silt & $0.0425-0.1068$ & $0.49-0.47$ & - & - & - & \\
\hline Sandy Clay Loam & $0.0128-0.0653$ & $0.45-0.42$ & $0.0248-0.0094$ & $0.44-0.37$ & 0.0296 & 0.42 \\
\hline Clay Loam & $0.0122-0.0256$ & $0.50-0.45$ & $0.0142-0.0024$ & $0.48-0.40$ & 0.0083 & 0.48 \\
\hline Silty Clay Loam & $0.0183-0.0252$ & $0.53-0.49$ & $0.0118-0.0165$ & $0.50-0.43$ & 0.0024 & 0.48 \\
\hline Sandy Clay & $0.0003-0.0088$ & $0.46-0.43$ & 0.0035 & 0.39 & 0.0035 & 0.43 \\
\hline Silty Clay & $0.0115-0.0118$ & $0.55-0.50$ & 0.0059 & 0.53 & 0.0012 & 0.49 \\
\hline Clay & $0.0103-0.0056$ & $0.56-0.46$ & $0.0071-0.0060$ & $0.48-0.40$ & 0.0071 & 0.48 \\
\hline
\end{tabular}




\section{Appendix B - Weather Data}

\begin{tabular}{|c|c|c|c|c|c|}
\hline \multicolumn{6}{|c|}{ METEORLOGICAL DATA } \\
\hline STATION & SAN FELIX & HATO PILON & CAMARON ARRIBA & QUEBRADA LORO & CANDELA \\
\hline Data & $1 / 9 / 71$ - present & $1 / 9 / 71-1 / 3 / 2000$ & $1 / 12 / 74-1 / 12 / 98$ & $1 / 2 / 93$ - present & $4 / 19 / 13-6 / 7 / 14$ \\
\hline Elevation (msnm) & 110 & 635 & 480 & 390 & 290 \\
\hline Aspect & South & East & Southwest & South & West \\
\hline Watershed Distance $(\mathrm{km})$ & 10.9 & 3.4 & 11 & 3.2 & 0.7 \\
\hline Month & Avg Rain (mm) & Avg Rain (mm) & Avg Rain (mm) & Avg Rain (mm) & Avg Rain (mm) \\
\hline January & 28 & 22 & 11 & 29 & 23 \\
\hline Febuary & 23 & 19 & 9 & 20 & 9 \\
\hline March & 49 & 50 & 38 & 63 & 16 \\
\hline April & 104 & 182 & 126 & 142 & 72 \\
\hline May & 465 & 594 & 397 & 639 & 210 \\
\hline June & 489 & 602 & 533 & 676 & 260 \\
\hline July & 458 & 451 & 412 & 603 & 502 \\
\hline August & 563 & 646 & 484 & 726 & 280 \\
\hline September & 616 & 820 & 645 & 750 & 674 \\
\hline October & 657 & 994 & 745 & 857 & 730 \\
\hline November & 459 & 487 & 394 & 580 & 409 \\
\hline December & 130 & 115 & 80 & 171 & 50 \\
\hline \multirow[t]{2}{*}{ Annual } & 4039 & 4983 & 3874 & 5257 & 3236 \\
\hline & Local Monthly Rai & all (mm) & & & \\
\hline Month & Gov't Stations & Local Station & Average Rainfall & \multicolumn{2}{|c|}{ Avg. Temperature (C) } \\
\hline January & 23 & 23 & 23 & & 24.9 \\
\hline February & 18 & 9 & 13 & & 25.6 \\
\hline March & 51 & 16 & 34 & & 26.5 \\
\hline April & 136 & 72 & 104 & & 26.4 \\
\hline May & 526 & 210 & 368 & & 25.1 \\
\hline June & 582 & 260 & 421 & & 24.8 \\
\hline July & 492 & 502 & 497 & & 23.9 \\
\hline August & 609 & 280 & 445 & & 24.4 \\
\hline September & 703 & 674 & 688 & & 24.3 \\
\hline October & 804 & 730 & 767 & & 24.4 \\
\hline November & 486 & 409 & 448 & & 24.5 \\
\hline December & 128 & 50 & 89 & & 25 \\
\hline Total & 4557 & 3236 & 3896 & & 25.0 \\
\hline
\end{tabular}


Appendix C - Spring Flow Data

\begin{tabular}{|c|c|c|c|}
\hline \multicolumn{4}{|c|}{ Spring Discharge $\left(\mathrm{m}^{3} /\right.$ day $)$} \\
\hline Date & LDS & UPS & Combined \\
\hline 26-Apr-13 & 1.4 & 10.3 & 11.7 \\
\hline 3-Мау-13 & 4.3 & 11.4 & 15.7 \\
\hline 3-Jun-13 & 38.4 & 21.0 & 59.5 \\
\hline 6-Jun-13 & 86.4 & 23.4 & 109.8 \\
\hline 15-Jun-13 & 96.0 & 38.4 & 134.4 \\
\hline 19-Jun-13 & 181.7 & 72.0 & 253.7 \\
\hline 24-Jun-13 & 205.3 & 75.1 & 280.4 \\
\hline 28-Jun-13 & 142.4 & 73.2 & 215.6 \\
\hline 28-Jun-13 & 142.9 & 72.8 & 215.7 \\
\hline 28-Jun-13 & 136.6 & 73.6 & 210.2 \\
\hline 29-Jun-13 & 132.5 & 73.5 & 206.0 \\
\hline 29-Jun-13 & 137.5 & 75.2 & 212.7 \\
\hline 30-Jun-13 & 126.9 & 73.0 & 199.9 \\
\hline 5-Jul-13 & 242.7 & 111.0 & 353.7 \\
\hline $18-\mathrm{Jul}-13$ & 134.4 & 90.2 & 224.6 \\
\hline 28-Jul-13 & 174.9 & 111.6 & 286.5 \\
\hline 20 -Sep-13 & 817.7 & 395.2 & 1212.8 \\
\hline 2 -Oct-13 & 545.1 & 244.3 & 789.4 \\
\hline 7-Oct-13 & 218.0 & 181.5 & 399.6 \\
\hline 4-Nov-13 & 174.4 & 145.5 & 320.0 \\
\hline 21-Nov-13 & 136.3 & 118.8 & 255.1 \\
\hline $25-$ Nov-13 & 109.0 & 108.7 & 217.8 \\
\hline 6-Dec-13 & 105.5 & 98.3 & 203.9 \\
\hline 7-Dec-13 & 103.8 & 95.3 & 199.1 \\
\hline 8-Dec-13 & 102.0 & 93.5 & 195.5 \\
\hline 9-Dec-13 & 100.6 & 89.9 & 190.6 \\
\hline 10-Dec-13 & 102.2 & 90.2 & 192.4 \\
\hline 12-Dec-13 & 92.1 & 86.4 & 178.5 \\
\hline 19-Dec-13 & 81.8 & 72.7 & 154.4 \\
\hline 9-Jan-14 & 62.9 & 49.0 & 111.9 \\
\hline 14-Jan-14 & 54.5 & 43.3 & 97.8 \\
\hline 24-Jan-14 & 45.4 & 36.8 & 82.2 \\
\hline 28-Jan-14 & 43.0 & 35.2 & 78.2 \\
\hline 2-Feb-14 & 38.9 & 32.0 & 70.9 \\
\hline 3-Feb-14 & 37.2 & 31.9 & 69.1 \\
\hline 6-Feb-14 & 36.4 & 30.9 & 67.3 \\
\hline 16 -Feb-14 & 30.9 & 27.4 & 58.2 \\
\hline 20 -Feb-14 & 25.9 & 24.7 & 50.6 \\
\hline 23-Feb-14 & 24.1 & 23.5 & 47.6 \\
\hline 25-Feb-14 & 31.5 & 25.2 & 56.6 \\
\hline 2-Mar-14 & 15.6 & 22.9 & 38.5 \\
\hline 5-Mar-14 & 11.7 & 22.4 & 34.0 \\
\hline 7-Mar-14 & 13.6 & 22.0 & 35.6 \\
\hline 22-Mar-14 & 8.6 & 19.2 & 27.9 \\
\hline 6-Apr-14 & 3.1 & 15.0 & 18.1 \\
\hline 9-Apr-14 & 2.7 & 16.2 & 18.9 \\
\hline 11-Apr-14 & 2.3 & 15.8 & 18.2 \\
\hline 12-Apr-14 & 4.4 & 15.9 & 20.3 \\
\hline 18-Apr-14 & 2.6 & 15.8 & 18.4 \\
\hline 20-Apr-14 & 11.1 & 15.5 & 26.5 \\
\hline 23-Apr-14 & 2.7 & 15.8 & 18.5 \\
\hline 25-Apr-14 & 8.4 & 14.8 & 23.2 \\
\hline 30-Apr-14 & 0.1 & 14.7 & 14.9 \\
\hline 1-Мау-14 & 0.1 & 15.2 & 15.3 \\
\hline 3-May-14 & 0.1 & 15.2 & 15.3 \\
\hline 5-Мау-14 & 2.8 & 15.3 & 18.0 \\
\hline 12-Мау-14 & 44.2 & 18.9 & 63.1 \\
\hline 15-Мау-14 & 23.3 & 18.2 & 41.5 \\
\hline 18-Мау-14 & 9.9 & 18.5 & 28.5 \\
\hline 21-Мay-14 & 5.9 & 18.8 & 24.7 \\
\hline 21-Мay-14 & 5.1 & 18.8 & 23.9 \\
\hline 21-May-14 & 4.8 & 18.8 & 23.5 \\
\hline 23-Мay-14 & 4.2 & 18.8 & 22.9 \\
\hline 24-May-14 & 3.9 & 19.4 & 23.3 \\
\hline 27-May-14 & 21.3 & 21.2 & 42.5 \\
\hline 31-Мay-14 & 31.5 & 24.2 & 55.7 \\
\hline 1-Jun-14 & 49.5 & 24.6 & 74.1 \\
\hline 5-Jun-14 & 44.2 & 27.6 & 71.8 \\
\hline 7-Jun-14 & 56.4 & 29.3 & 85.6 \\
\hline
\end{tabular}

